Prepared in cooperation with the California Department of Transportation

\title{
Approaches for Assessing Long-Term Annual Yields of Highway and Urban Runoff in Selected Areas of California with the Stochastic Empirical Loading and Dilution Model (SELDM)
}

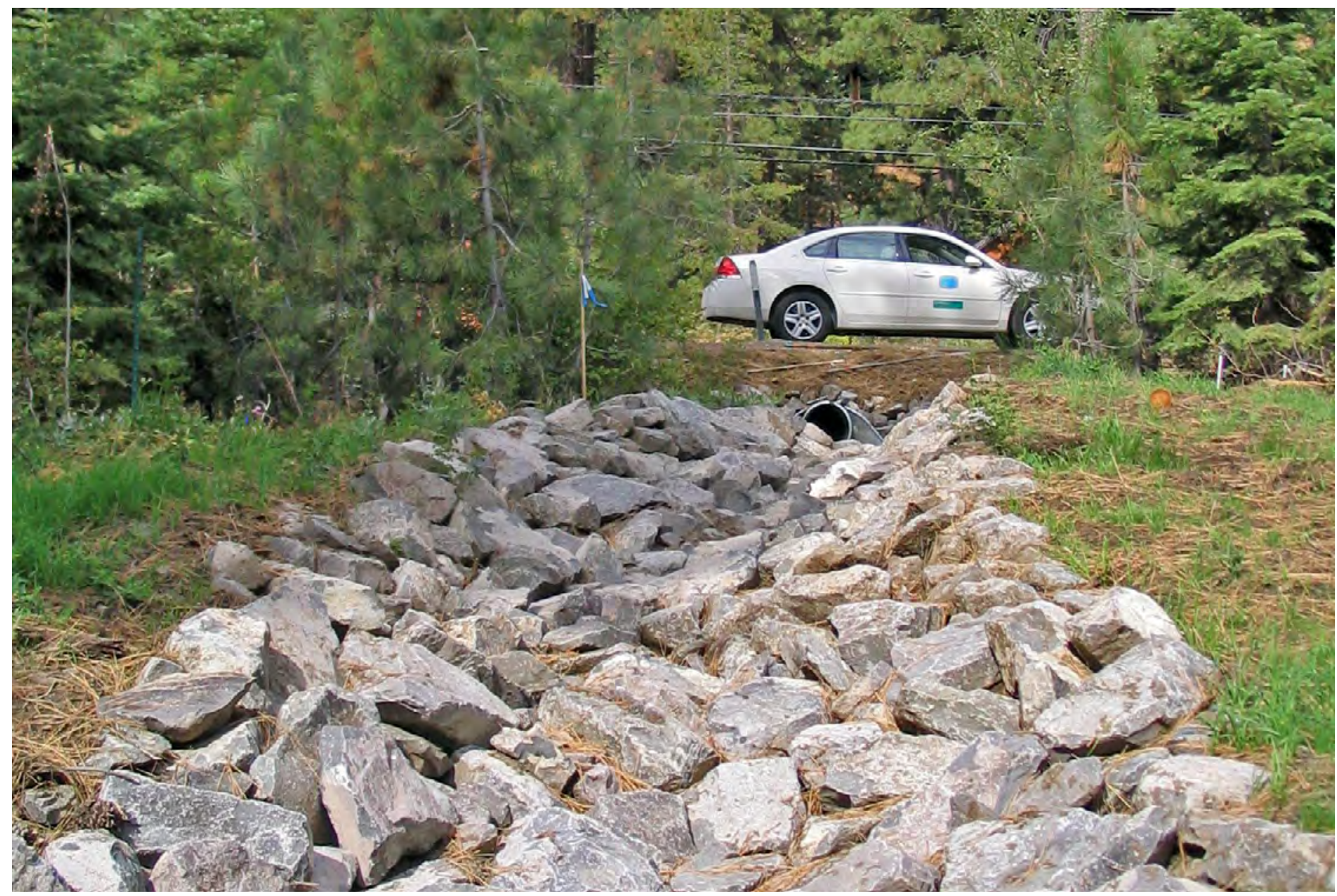

Scientific Investigations Report 2021-5043 
Cover. Riprap swale constructed by the California Department of Transportation as part of a treatment train to direct stormwater runoff from Route 28 in Kings Beach, California. Photograph by the California Department of Transportation. 


\section{Approaches for Assessing Long-Term Annual Yields of Highway and Urban Runoff in Selected Areas of California with the Stochastic Empirical Loading and Dilution Model (SELDM)}

By Gregory E. Granato and Paul J. Friesz

Prepared in cooperation with the California Department of Transportation

Scientific Investigations Report 2021-5043 


\section{U.S. Geological Survey, Reston, Virginia: 2021}

For more information on the USGS - the Federal source for science about the Earth, its natural and living resources, natural hazards, and the environment—visit https://www.usgs.gov or call 1-888-ASK-USGS.

For an overview of USGS information products, including maps, imagery, and publications, visit https://store.usgs.gov/.

Any use of trade, firm, or product names is for descriptive purposes only and does not imply endorsement by the U.S. Government.

Although this information product, for the most part, is in the public domain, it also may contain copyrighted materials as noted in the text. Permission to reproduce copyrighted items must be secured from the copyright owner.

Suggested citation:

Granato, G.E., and Friesz, P.J., 2021, Approaches for assessing long-term annual yields of highway and urban runoff in selected areas of California with the Stochastic Empirical Loading and Dilution Model (SELDM): U.S. Geological Survey Scientific Investigations Report 2021-5043, 37 p., https://doi.org/10.3133/sir20215043.

Data accompanying this publication:

Granato, G.E., and Friesz, P.J., 2021, Model archive for assessing long-term annual yields of highway and urban runoff in selected areas of California with the Stochastic Empirical Loading and Dilution Model (SELDM): U.S. Geological Survey data release, https://doi.org/10.5066/P9B02EUZ.

ISSN 2328-0328 (online) 


\section{Acknowledgments}

The authors thank the many people who assisted with this report and the associated digital media. Bhaskar Joshi and Bala Nanjundiah of the California Department of Transportation, Division of Environmental Analysis, helped design the study and provided oversight, information, and data for the study. Bhaskar Joshi and Joshua Gualco of the California Department of Transportation, Division of Environmental Analysis, and Dipen Patel of the California State University, Office of Water Programs, provided a report review that improved the content and presentation of information in this report. The authors thank Laura Medalie of the U.S. Geological Survey (USGS) for assistance with the geographic and water-quality compilations. The authors also thank Alana Spaetzel and Adam Stonewall of the USGS for providing thoughtful and thorough technical and editorial reviews that greatly improved this report and the associated data release model archive. 



\section{Contents}

Acknowledgments ……...................................................................................................................

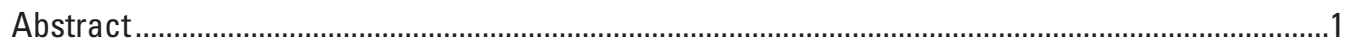

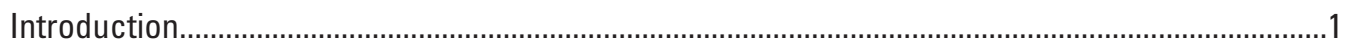

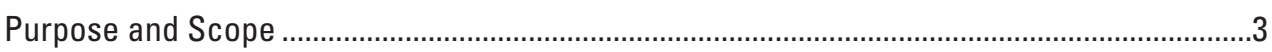

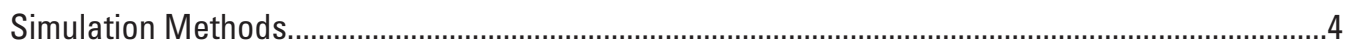

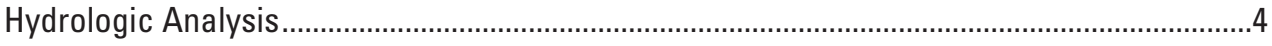

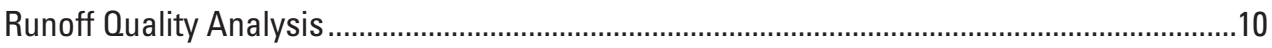

Runoff Treatment Analysis ................................................................................................. 18

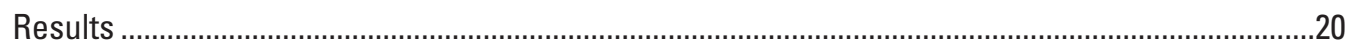

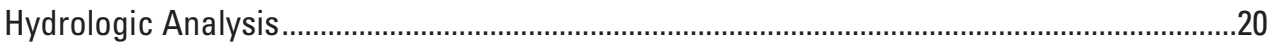

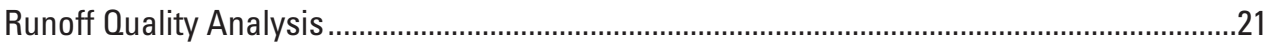

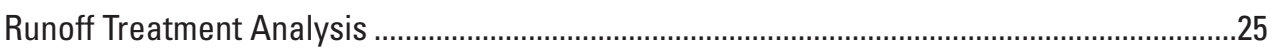

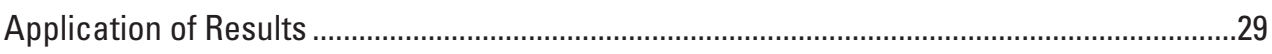

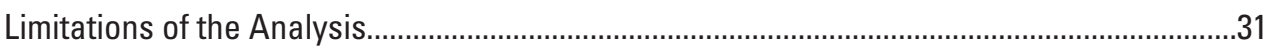

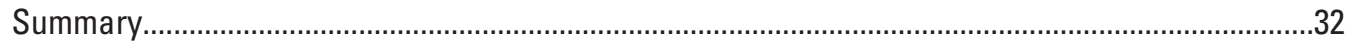

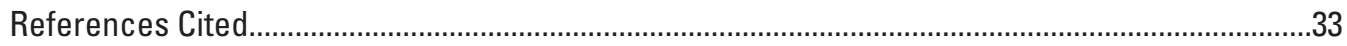

\section{Figures}

1. Map showing U.S. Environmental Protection Agency level III ecoregions of California

2. Graphs showing precipitation statistics of selected sites in California used with the Stochastic Empirical Loading and Dilution Model .....................................................

3. Scatter plot showing the annual average daily traffic counts at California Department of Transportation traffic-census monitoring sites and highway runoff monitoring sites...

4. Scatter plot showing the precipitation, runoff, and structural best management practice discharge by event in ecoregion 6 simulated by using the Stochastic Empirical Loading and Dilution Model

5. Scatter plot showing precipitation, runoff, and structural best management practice discharge by annual load accounting year in ecoregion 6 simulated by using the Stochastic Empirical Loading and Dilution Model..

6. Scatter plot showing constituent concentrations in highway and urban runoff and in structural best management practice discharge by event, that were simulated by using the Stochastic Empirical Loading and Dilution Model.

7. Scatter plot showing constituent yields in highway and urban runoff and in structural best management practice discharge by annual load accounting year, that were simulated by using the Stochastic Empirical Loading and Dilution Model 


\section{Tables}

1. Definition and ownership of road classes in California ......................................................2

2. U.S. Environmental Protection Agency level III ecoregions of California ..........................5

3. Synoptic precipitation statistics for selected U.S. Environmental Protection Agency level III ecoregions of California

4. Synoptic precipitation statistics representing the median of selected-station values used for annual-yield analyses in California with the Stochastic Empirical Loading and Dilution Model

5. Runoff quality constituents used to simulate highway and urban runoff quality in selected areas of California with counts of the number of highway and urban runoff sites and the best management practices treatment analysis method.

6. Statistics used to simulate highway-runoff quality in California with the Stochastic Empirical Loading and Dilution Model

7. National urban-runoff quality statistics used to simulate urban-runoff quality in California with the Stochastic Empirical Loading and Dilution Model 15

8. Median of selected stormflow volume-reduction statistics for the trapezoidal distribution and Spearman's rho correlation coefficient statistics for best management practices, by category.

9. Average annual yields of selected constituents in highway or urban runoff and structural stormwater best management practice discharge in ecoregion 6 , simulated by the Stochastic Empirical Loading and Dilution Model.

10. Selected StreamStats basin properties for streams and rivers in total maximum daily load areas of California

\section{Conversion Factors}

U.S. customary units to International System of Units

\begin{tabular}{lcl}
\hline \multicolumn{1}{c}{ Multiply } & By & \multicolumn{1}{c}{ To obtain } \\
\hline inch (in.) & 25.4 & millimeter $(\mathrm{mm})$ \\
mile (mi) & 1.609 & kilometer $(\mathrm{km})$ \\
acre & 0.4047 & hectare $(\mathrm{ha})$ \\
square mile $\left(\mathrm{mi}^{2}\right)$ & 259.0 & hectare $(\mathrm{ha})$ \\
pound, avoirdupois $(\mathrm{lb})$ & 0.4536 & kilogram $(\mathrm{kg})$ \\
pound per acre per year $([\mathrm{lb} / \mathrm{ac}] / \mathrm{yr})$ & 1.121 & kilogram per hectare per year $([\mathrm{kg} / \mathrm{ha}] / \mathrm{yr})$ \\
\hline
\end{tabular}

\section{Supplemental Information}

Specific conductance is given in microsiemens per centimeter at 25 degrees Celsius $(\mu \mathrm{S} / \mathrm{cm}$ at $\left.25^{\circ} \mathrm{C}\right)$.

Concentrations of chemical constituents in water are given in milligrams per liter (mg/L), micrograms per liter ( $\mu \mathrm{g} / \mathrm{L})$, or nanograms per liter $(\mathrm{ng} / \mathrm{L})$.

Bacterial concentrations are given in colonies per 100 milliliters or most probable number per 100 milliliters. 


\section{Abbreviations}

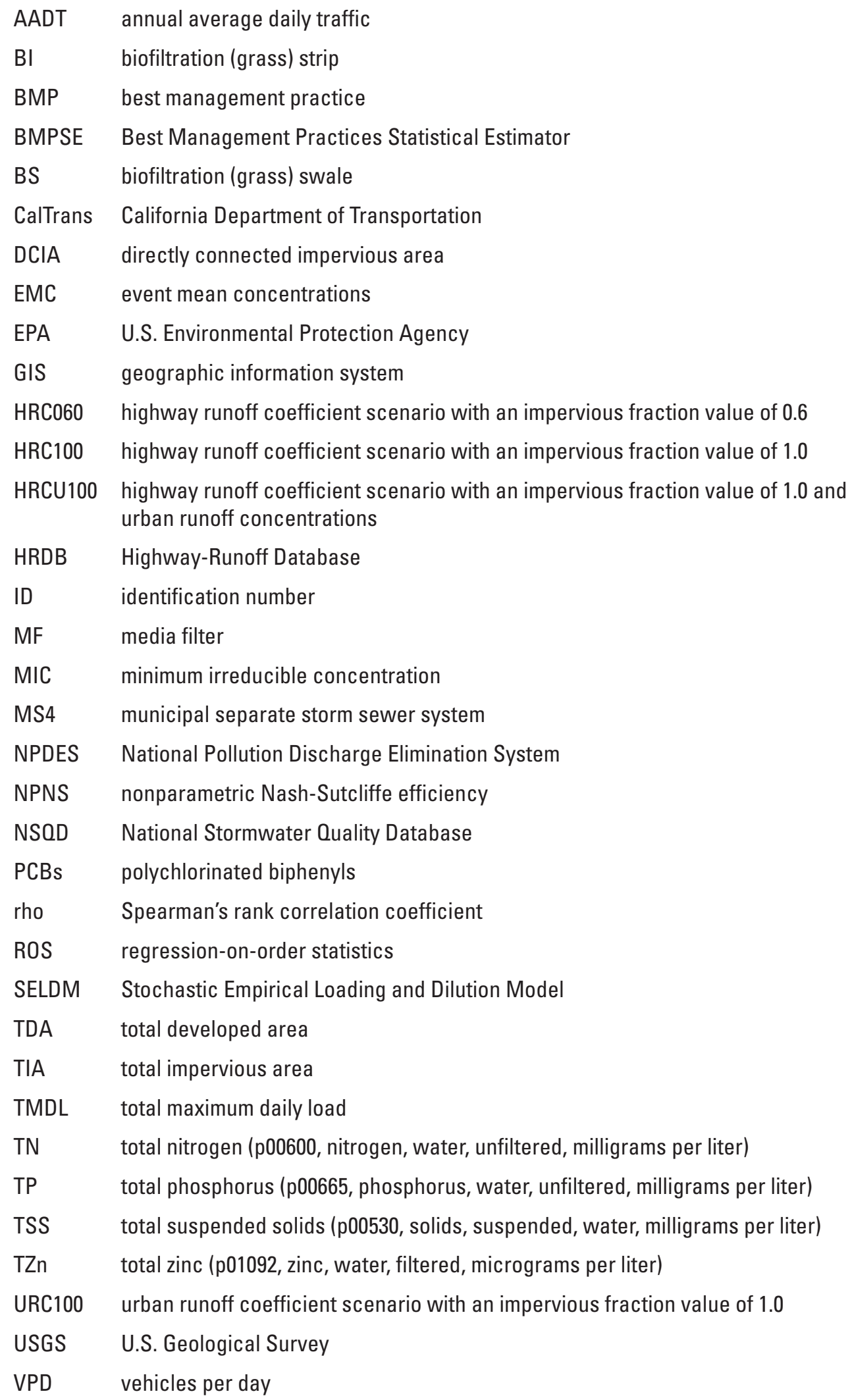





\title{
Approaches for Assessing Long-Term Annual Yields of Highway and Urban Runoff in Selected Areas of California with the Stochastic Empirical Loading and Dilution Model (SELDM)
}

\author{
By Gregory E. Granato and Paul J. Friesz
}

\section{Abstract}

The California Department of Transportation, commonly known as CalTrans, and other municipal separate storm sewer system permittees in California as well as other State departments of transportation nationwide need information about potential loads and yields (loads per unit area) of constituents of concern in stormwater runoff and discharges from stormwater best management practices (BMPs). Although its National Pollution Discharge Elimination System stormwater permit is focused on areas subject to total maximum daily load (TMDL) regulations, CalTrans builds and maintains BMPs to minimize the adverse effects of roadway runoff on receiving waters throughout the State. This report describes approaches used by the U.S. Geological Survey in cooperation with CalTrans for using the Stochastic Empirical Loading and Dilution Model (SELDM) to assess long-term annual yields of highway and urban runoff in selected areas of California. In this study, a series of regional and local yields were simulated to provide statewide planning-level estimates and more refined TMDLspecific yield values. SELDM was used to analyze 368 State roadway and urban runoff yields for 53 runoff quality constituents. The analyses included 222 random-seed analyses, 60 regional State roadway-runoff analyses, 24 regional urban roadway-runoff analyses, and 62 focused TMDL-area analyses.

This report describes approaches and statistics used to analyze available hydrologic and runoff quality data in all analyses. Results for all analyses are provided in the model archive, but only a selected subset of results are presented as examples in this report. State roadway runoff, urban runoff, and BMP discharge yields for total suspended solids, total nitrogen, total phosphorus, and total zinc were selected as examples because they are widespread constituents of concern with substantial amounts of State roadway and urban runoff monitoring data. In this report, a hypothetical basin was specified by using available geographic information to demonstrate use of the State roadway and urban runoff yields to estimate long-term annual stormwater loads from developed areas.
Application of these yields to the hypothetical basin indicates that although State-roadway yields may be higher than urbanrunoff yields for some constituents, State-roadway loads may be a small proportion of total stormwater loads because State roadways themselves are a small fraction of the total impervious area in such basins. Although application of results from this study may have considerable uncertainty for any particular stormwater outfall, the study does provide robust estimates to support basin-scale runoff-load analyses in California. These analyses also provide estimates for the 12 U.S. Environmental Protection Agency level III ecoregions that are completely or partially within the boundaries of the State of California.

\section{Introduction}

The California Department of Transportation, commonly known as CalTrans, is responsible for maintaining 350,000 acres of right of way, 15,133 centerline miles, more than 50,000 lane miles of State roadways, and 4,669 bridges or large culverts over water in the State (California Department of Transportation, 2020a, c; Federal Highway Administration, 2020). The population of bridges and culverts crossing waterways comprises 1,404 principal arterial interstate highways, 2,033 principal arterial State highways, 1,073 minor arterial State roads, and 48 other roads (Federal Highway Administration, 2020). The 2014 highway census indicates that CalTrans operates about 4,050 miles of limited access highways, 10,190 miles of other arterial highways, and 860 miles of lower capacity roads (table 1; Federal Highway Administration, 2015). Although its primary mission is to "provide a safe, sustainable, integrated and efficient transportation system to enhance California's economy and livability" (California Department of Transportation, 2020a), CalTrans also manages runoff from its roadways to meet responsibilities under Federal and State environmental law as an important part of its mission (California Department of Transportation, 2016, 2020b, d; California State Water Resources Control Board, 2017). In its National Pollution Discharge Elimination 
Table 1. Definition and ownership of road classes in California.

[Road statistics are from Federal Highway Administration (2015). Road classes are listed in order of increasing functional class. Official road-class definitions are not quantitative. For more extensive definitions see Federal Highway Administration (2013) or American Association of State Highway and Transportation Officials (2001). mi, mile; - , not applicable]

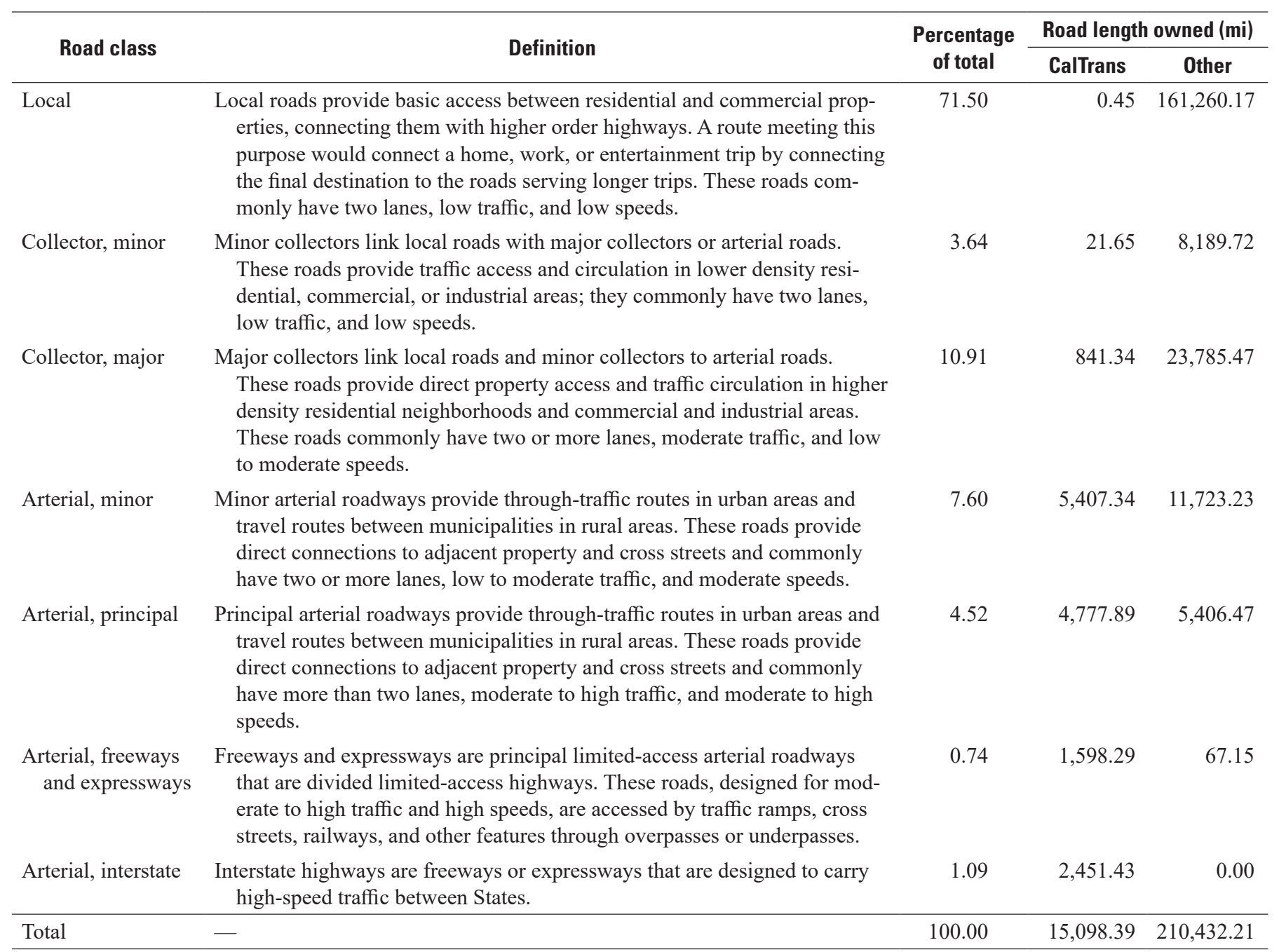

System (NPDES) statewide stormwater permit, CalTrans is identified as a stakeholder in 84 areas subject to total maximum daily load (TMDL) regulations (California State Water Resources Control Board, 2017).

As indicated by the number of bridges and large culverts crossing waterways (Federal Highway Administration, 2020), CalTrans maintains thousands of stormwater outfalls and structural stormwater treatment facilities, commonly known as structural stormwater best management practices (BMPs). Although its NPDES permit is focused on TMDL areas, CalTrans builds and maintains BMPs to minimize the adverse effects of roadway runoff on receiving waters throughout the State (California Department of Transportation, 2016, 2020d). Such facilities are costly to build and maintain with life-cycle costs that can exceed $\$ 70,000$ per pound per year for some constituents of concern (Taylor and others, 2014). Under existing agreements with the California State Water
Resources Control Board, CalTrans is annually required to add 1,650 compliance units, each of which is equivalent to an acre of highway mitigation or $\$ 88,000$ to fund municipal mitigation measures (California Department of Transportation, 2018a). Therefore, CalTrans and other Municipal Separate Storm Sewer System (MS4) permittees in California and other State departments of transportation nationwide need information about potential yields (loads per unit area) of constituents of concern in stormwater runoff and BMP discharges. Lantin and others (2019) concluded that the Stochastic Empirical Loading and Dilution Model (SELDM) developed by the U.S. Geological Survey (USGS) in cooperation with the Federal Highway Administration is a useful method for estimating runoff and BMP discharge yields for State departments of transportation. Similarly, Granato and Jones (2017), Smith and others (2018), and Stonewall and others (2018) demonstrated the use of SELDM to simulate long-term average 
annual yields in runoff and BMP discharges from roadways and other land covers to provide information needed for decision making.

Although the word "highway" may connote an image of a limited access freeway or expressway, a highway is defined as any publicly maintained road, street, or parkway (23 U.S. Code §101). In this report, the term highway will be used to include all roadways owned by CalTrans (table 1). The Highway-Runoff Database (HRDB) for CalTrans and other States includes runoff data from many different road classesfrom two-lane rural routes to multilane ultra-urban expressways (Granato and Friesz, 2021).

SELDM was developed for simulating stormwater event mean concentrations (EMCs) to indicate the risk for stormwater flows, concentrations, and loads to be above user-selected water-quality goals and to evaluate the potential effectiveness of mitigation measures to reduce such risks (Granato, 2013, 2014; Granato and Jones, 2014, 2017, 2019). The runoff coefficient statistics are a function of the imperviousness of the site of interest. Although SELDM is nominally a roadwayrunoff model, it is a lumped parameter model that can be used to simulate runoff from various land covers (Granato, 2013; Stonewall and others, 2018; Jeznach and Granato, 2020). SELDM uses the U.S. Environmental Protection Agency (EPA) definition of a runoff-producing event to do Monte Carlo simulations that represent possible conditions at a site of interest over a long period of time. SELDM is not calibrated by fitting input values to a historical record; it is calibrated by selecting statistics for runoff quality variables and BMP treatment variables from robust and representative datasets (Granato, 2013, 2014; Granato and Jones, 2014, 2017; Granato and others, 2021). SELDM can use the EPA level III ecoregions (Omernik and others, 2003) as areas of hydrologic similarity to develop regional planning-level estimates of stormwater characteristics. These regional planning-level estimates can be refined by using more site-specific input statistics or user-defined values.

SELDM simulates each storm event in an analysis and assigns a sequence number and an annual load accounting year (Granato, 2013). When the time between event midpoints (delta) of a series of simulated events exceeds 365 or 366 days, those events are lumped into one annual load accounting year. SELDM generates each storm randomly; there is no serial correlation. The order of storms does not reflect seasonal patterns. The annual load accounting years, which are randomly generated collections of events with sums of interevent times less than or equal to a year, are used to generate annual highway flows and loads. These annual values can be used for TMDL analyses (Granato and Jones, 2017; Lantin and others, 2019).

SELDM produces an annual highway runoff loads output file that includes five annual hydrologic variables, including the precipitation total for runoff-generating events, total roadway-runoff flow, runoff flow normalized to the highway drainage area, the BMP discharge flow, and the BMP discharge flow normalized to the roadway drainage area. The annual output file also includes two water-quality variables, which are the annual roadway runoff and the BMP discharge loads. This annual output file facilitates analysis of TMDLs by recording the simulated annual contributions of a site of interest to a receiving water body. The simulated population of annual runoff loads from the site of interest indicates the potential highway or urban contribution and the long-term annual variability in such loads. The simulated population of annual runoff loads from the BMP discharge indicates the potential for reducing the highway or urban loads to meet any proposed load allocations. If the site of interest for a given land cover is simulated as one acre, then SELDM produces a population of runoff and BMP discharge yields in pounds per acre. Once yields for different land covers are calculated, information about different land-cover areas obtained from a geographic information system (GIS) can be used to estimate total loads from each land-cover area in a stream basin of interest (Stonewall and others, 2018).

\section{Purpose and Scope}

This report describes approaches and statistics used to analyze available hydrologic and runoff quality data by simulating long-term annual yields of highway and urban runoff constituents of concern with SELDM (version 1.1.0; Granato, 2021b). In this study, a series of regional- and localarea simulations were done to provide statewide planninglevel estimates and TMDL specific yield values. This report includes examples selected to illustrate the approaches used by Granato and Friesz (2021) to simulate highway and urban runoff and BMP discharge yields in California. The study described in this report was done by the USGS in cooperation with CalTrans.

In these analyses, regional or local precipitation statistics were used with runoff coefficient statistics developed by the USGS in cooperation with the Federal Highway Administration to generate a population of highway or urban runoff flows (Granato, 2010a, 2013). Representative water-quality statistics were calculated to generate a population of runoff EMCs. The flows and EMCs were used to simulate event runoff yields and annual yields, which are the totals of event yields within annual load accounting years. Representative BMP treatment statistics (Granato and others, 2021) were used to modify runoff flows and EMC values to simulate populations of event and annual BMP discharge yields. A hypothetical basin was simulated by using available geographic information to demonstrate use of highway and urban yields to estimate long-term annual stormwater loads from developed areas. These data, information, and statistics are intended to facilitate stochastic analysis of the potential effects of stormwater runoff on receiving waters at unmonitored sites (or sites with limited monitoring data). The methods and statistics described in this report were designed for use with SELDM but may be used with other methods or models. 


\section{Simulation Methods}

SELDM uses Monte Carlo methods to generate a population of random precipitation, flow, concentration, and treatment values that are grouped into annual load accounting years but do not represent any particular time period or a particular time series (Granato, 2013). SELDM is calibrated by using representative input statistics rather than by adjusting model parameters so that model outputs match a limited set of measured values. The model simulates hydrologic, runoff quality, and runoff treatment variables stochastically by using literature and public-database-derived statistics for hundreds to thousands of sites (Granato, 2010a, 2013, 2014; Granato and others, 2021).

If, as in this study, SELDM is being used only to generate loads or yields from a site of interest and is not being used to simulate receiving-water contributions downstream of a particular discharge point for individual storm events, then the upstream and downstream results are not needed (Granato, 2013). In this type of study, hypothetical input values can be used. The upstream-basin variables, which include the upstream-basin properties, prestorm flow, and upstream water quality, must be specified but are not used to generate loads or yields from the (highway) site of interest. The highway hydrograph timing variables (the length, slope, and basin development factor) also must be specified but are not used to generate loads or yields from the site of interest. Therefore, the input and output variables for determining the upstream and downstream stormflow, concentrations, and loads documented by Granato and Friesz (2021) are hypothetical values that do not represent conditions at any particular site.

\section{Hydrologic Analysis}

The three hydrologic variables needed for producing estimates of long-term average annual highway and urban runoff yields are the drainage area of the site of interest, the precipitation statistics, and the runoff coefficient statistics for that site (Granato, 2013; Granato and Jones, 2017; Stonewall and others, 2018). The drainage area used for the hypothetical sites of interest was one acre so that the results could be used directly as stormwater yields. In this study, a series of regional simulations was done to provide statewide planning-level estimates and a series of local simulations was done to develop specificyield values for TMDL basins (Granato and Friesz, 2021).

The regional simulations were done by using precipitation statistics for the $12 \mathrm{EPA}$ level III ecoregions that lie in whole or in part within the State of California (fig.1; table 2). Regional statistics provide initial planning-level estimates that can be applied at sites without the need for local precipitation data. Table 3 shows synoptic precipitation statistics that were calculated for the selected ecoregions by using the EPA definition of a runoff-generating event with a minimum interevent time of 6 hours and a minimum precipitation volume

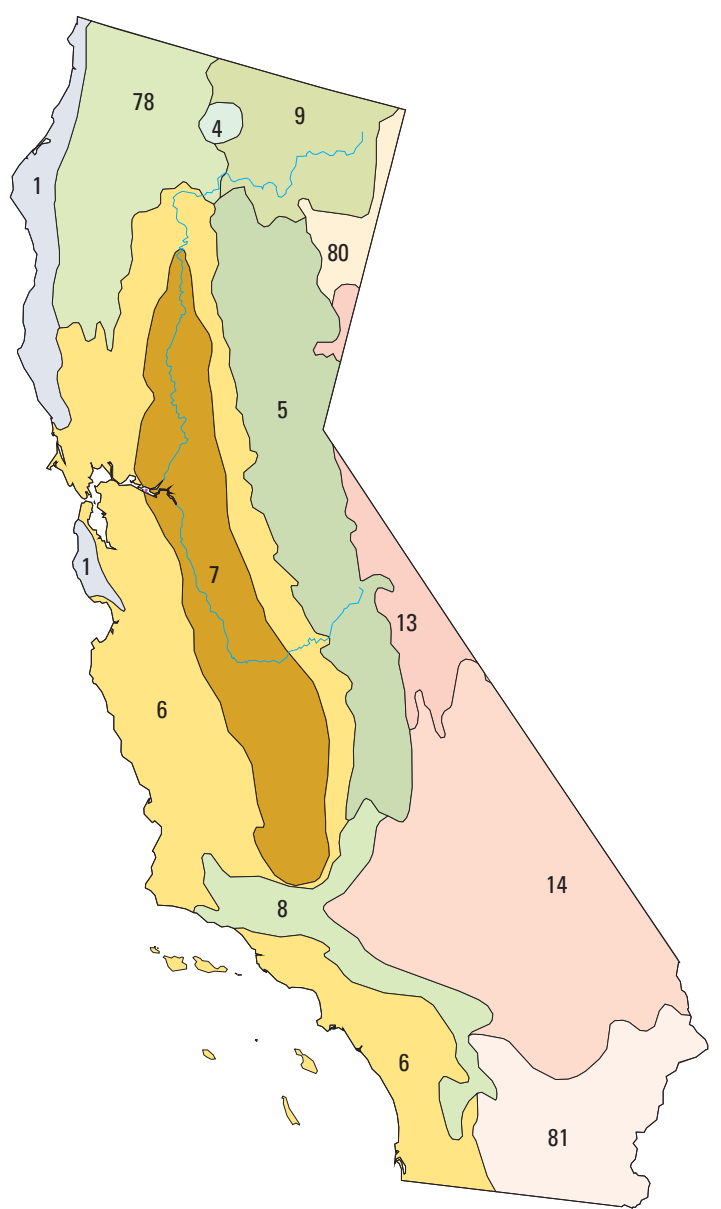

Base map from U.S. Environmental Protection Agency digital data, 2003

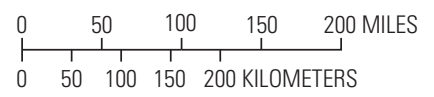

\section{EXPLANATION}

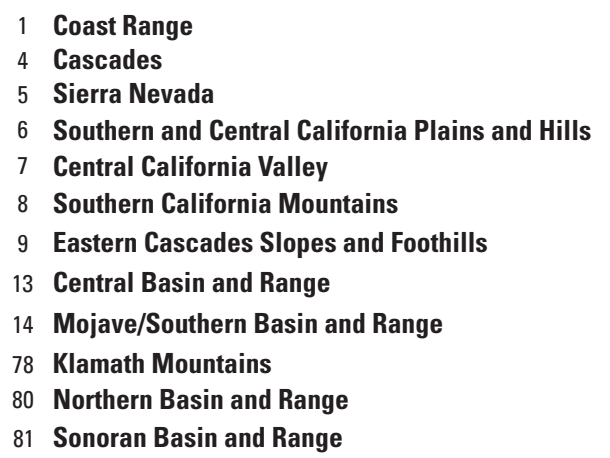

Figure 1. Map showing U.S. Environmental Protection Agency level III ecoregions that lie in whole or in part within the State of California. The Stochastic Empirical Loading and Dilution Model (SELDM) for California was built on the basis of a discretized version of the 2003 ecoregions (Omernik and others, 2003). 
Table 2. U.S. Environmental Protection Agency level III ecoregions that lie in whole or in part within the State of California.

[Ecoregion numbers, names, and definitions are defined by the U.S. Environmental Protection Agency (Omernik and others, 2003). SELDM area is the discretized area of each ecoregion in the Stochastic Empirical Loading and Dilution Model (Granato, 2013) calculated by using the number of grid cells and the average area of a 0.25 -degree grid cell in the ecoregion; calculated areas are for the entire ecoregion (not just the area in California). $\mathrm{mi}^{2}$, square mile]

\begin{tabular}{|c|c|c|c|}
\hline \multicolumn{3}{|r|}{ U.S. Environmental Protection Agency level III ecoregion definitions } & \multirow{2}{*}{$\begin{array}{l}\text { SELDM, } \\
\text { area } \\
\left(\mathrm{mi}^{2}\right)\end{array}$} \\
\hline $\begin{array}{c}\text { Ecoregion } \\
\text { number }\end{array}$ & Name & Definition & \\
\hline 5 & Sierra Nevada & $\begin{array}{l}\text { The Sierra Nevada ecoregion is a deeply dissected block fault that rises sharply from the arid } \\
\text { basin-and-range ecoregions on the east and slopes gently toward the Central California } \\
\text { Valley to the west. The eastern part has been strongly glaciated and generally contains } \\
\text { higher mountains than are found in the Klamath Mountains to the northwest. Most of the } \\
\text { central and southern parts of the region is underlain by granite as compared to the mostly } \\
\text { sedimentary formations of the Klamath Mountains and volcanic rocks of the Cascades. } \\
\text { The higher elevations of this region are largely federally owned and include several na- } \\
\text { tional parks. The vegetation grades from mostly ponderosa pine at the lower elevations on } \\
\text { the west side and lodgepole pine on the east side to fir and spruce at the higher elevations. } \\
\text { Alpine conditions exist at the highest elevations. }\end{array}$ & 21,248 \\
\hline 6 & $\begin{array}{l}\text { Southern and } \\
\text { Central } \\
\text { California } \\
\text { Plains and Hills }\end{array}$ & $\begin{array}{l}\text { The primary distinguishing characteristic of this ecoregion is its Mediterranean climate of } \\
\text { hot, dry summers and cool, moist winters, and its associated vegetative cover composed } \\
\text { mainly of chaparral and oak woodlands; grasslands are found at some lower elevations, } \\
\text { and patches of pine are found at higher elevations. Most of the region consists of open } \\
\text { low mountains or foothills, but there are areas of irregular plains in the south and near the } \\
\text { border of the adjacent Central California Valley ecoregion. Much of this region is grazed } \\
\text { by domestic livestock; very little land has been cultivated. }\end{array}$ & 48,262 \\
\hline 7 & $\begin{array}{l}\text { Central California } \\
\text { Valley }\end{array}$ & $\begin{array}{l}\text { Flat, intensively farmed plains having long, hot, dry summers and cool, wet winters distin- } \\
\text { guish the Central California Valley from its neighboring ecoregions that are either hilly } \\
\text { or mountainous, forest or shrub covered, and generally nonagricultural. Nearly half of the } \\
\text { region is cropland, about three fourths of which is irrigated. Environmental concerns in the } \\
\text { region include salinity caused by the evaporation of irrigation water, groundwater contami- } \\
\text { nation from heavy use of agricultural chemicals, wildlife habitat loss, and urban sprawl. }\end{array}$ & 17,518 \\
\hline 8 & $\begin{array}{l}\text { Southern } \\
\text { California } \\
\text { Mountains }\end{array}$ & $\begin{array}{l}\text { Like the other ecoregions in central and southern California, the Southern California } \\
\text { Mountains have a Mediterranean climate of hot, dry summers and moist, cool winters. } \\
\text { Although Mediterranean types of vegetation such as chaparral and oak woodlands pre- } \\
\text { dominate, the elevations are considerably higher in this region, the summers are slightly } \\
\text { cooler, and precipitation amounts are greater, causing the landscape to be more densely } \\
\text { vegetated and stands of ponderosa pine to be larger and more numerous than in the adja- } \\
\text { cent regions. Severe erosion is common where the vegetation cover has been destroyed by } \\
\text { fire or overgrazing. }\end{array}$ & 7,627 \\
\hline 9 & $\begin{array}{l}\text { Eastern Cascades } \\
\text { Slopes and } \\
\text { Foothills }\end{array}$ & $\begin{array}{l}\text { The Eastern Cascade Slopes and Foothills ecoregion is in the rain shadow of the Cascade } \\
\text { Mountains. Its climate exhibits greater temperature extremes and less precipitation than } \\
\text { ecoregions to the west. Open forests of ponderosa pine and some lodgepole pine distin- } \\
\text { guish this region from the higher ecoregions to the west, where fir and hemlock forests } \\
\text { are common, and also from the lower dryer ecoregions to the east, where shrubs and } \\
\text { grasslands are predominant. The vegetation has adapted to the prevailing dry continental } \\
\text { climate and is highly susceptible to wildfire. Volcanic cones and buttes are common in } \\
\text { much of the region. }\end{array}$ & 20,773 \\
\hline
\end{tabular}


Table 2. U.S. Environmental Protection Agency level III ecoregions that lie in whole or in part within the State of California. -Continued

[Ecoregion numbers, names, and definitions are defined by the U.S. Environmental Protection Agency (Omernik and others, 2003). SELDM area is the discretized area of each ecoregion in the Stochastic Empirical Loading and Dilution Model (Granato, 2013) calculated by using the number of grid cells and the average area of a 0.25 -degree grid cell in the ecoregion; calculated areas are for the entire ecoregion (not just the area in California). $\mathrm{mi}^{2}$, square mile]

\begin{tabular}{|c|c|c|c|}
\hline \multicolumn{3}{|r|}{ U.S. Environmental Protection Agency level III ecoregion definitions } & \multirow{2}{*}{$\begin{array}{c}\text { SELDM, } \\
\text { area } \\
\left(\mathrm{mi}^{2}\right)\end{array}$} \\
\hline $\begin{array}{c}\text { Ecoregion } \\
\text { number }\end{array}$ & Name & Definition & \\
\hline 14 & $\begin{array}{l}\text { Mojave/Southern } \\
\text { Basin and } \\
\text { Range }\end{array}$ & $\begin{array}{l}\text { This ecoregion contains scattered mountains that are generally lower than those of the } \\
\text { Central Basin and Range. Potential natural vegetation in this region is predominantly } \\
\text { creosote bush, as compared to the mostly saltbush-greasewood and Great Basin sagebrush } \\
\text { of the ecoregion to the north, and creosote bush-bur sage with large patches of paloverde } \\
\text { cactus shrub and saguaro cactus in the Sonoran Basin and Range to the south. Most of this } \\
\text { region is federally owned and there is relatively little grazing activity because of the lack } \\
\text { of water and forage for livestock. Heavy use of off-road vehicles and motorcycles in some } \\
\text { areas has caused severe wind and water erosion problems. }\end{array}$ & 49,728 \\
\hline 78 & $\begin{array}{l}\text { Klamath } \\
\text { Mountains }\end{array}$ & $\begin{array}{l}\text { The ecoregion is physically and biologically diverse. Highly dissected and folded mountains, } \\
\text { foothills, terraces, and flood plains occur and are underlain by igneous, sedimentary, and } \\
\text { some metamorphic rock. The mild, subhumid climate of the Klamath Mountains is charac- } \\
\text { terized by a lengthy summer drought. It supports a vegetal mix of northern Californian and } \\
\text { Pacific Northwest conifers. }\end{array}$ & 19,444 \\
\hline 80 & $\begin{array}{l}\text { Northern Basin } \\
\text { and Range }\end{array}$ & $\begin{array}{l}\text { This ecoregion contains arid tablelands, intermontane basins, dissected lava plains, and } \\
\text { scattered mountains. Nonmountain areas have sagebrush steppe vegetation; cool season } \\
\text { grasses and Mollisols are more common than in the hotter, drier basins of the Central } \\
\text { Basin and Range where Aridisols are dominated by sagebrush, shadscale, and greasewood. } \\
\text { Ranges are generally covered in mountain sagebrush, mountain brush, and Idaho fescue at } \\
\text { lower and mid-level elevations; Douglas fir, and aspen are common at higher elevations. } \\
\text { Overall, the ecoregion is drier and less suitable for agriculture than the Columbia Plateau } \\
\text { and higher and cooler than the Snake River Plain. Range land is common, and dry land } \\
\text { and irrigated agriculture are found in eastern basins. }\end{array}$ & 56,090 \\
\hline
\end{tabular}


Table 3. Synoptic precipitation statistics for selected U.S. Environmental Protection Agency level III ecoregions that lie in whole or in part within the State of California.

[U.S. Environmental Protection Agency level III ecoregions are defined in Omernik and others (2003) and listed in table 2. Synoptic precipitation statistics were calculated by using the definition of a runoff generating event with a minimum interevent time of 6 hours and a minimum precipitation volume of 0.1 inch of liquid precipitation. The statistics are the medians of statistics for each ecoregion from the National Oceanic and Atmospheric Administration (NOAA) hourly precipitation data stations with at least 25 years of data from 1965 to 2006 (Granato, 2010a). Delta is the time between storm event midpoints. in/yr, inch per year; in., inch; hr, hour; mi², square mile]

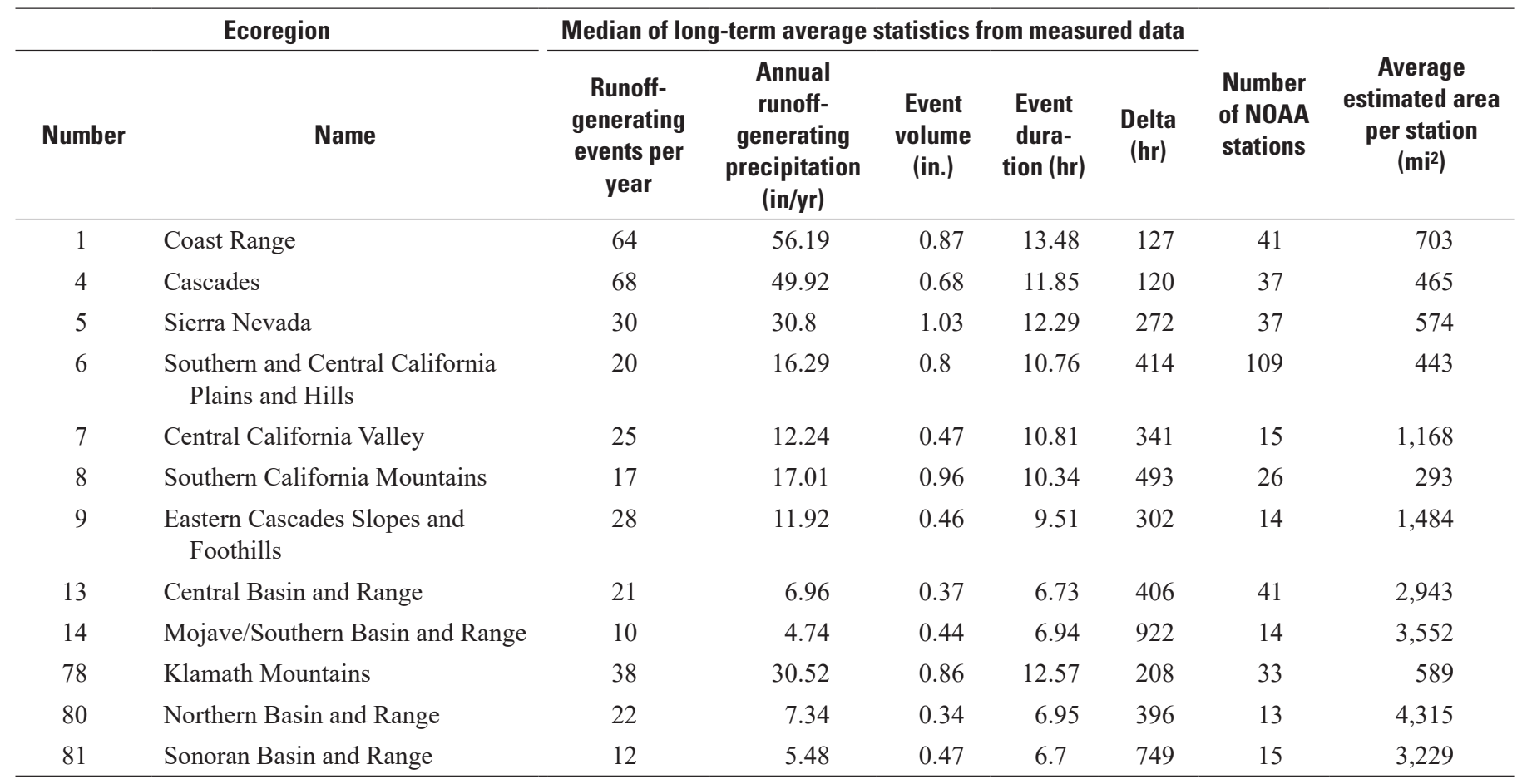

of 0.1 inch of liquid precipitation from National Oceanic and Atmospheric Administration hourly-precipitation data stations in each ecoregion with at least 25 years of data from 1965 to 2006 (Granato, 2010a). SELDM uses only four variables to generate the stochastic population of runoff events. The longterm average number of events per year is used to define the minimum number of events generated, and the event volume, duration, and the time between event midpoints (delta) are used to generate the long series of events that comprise a series of annual load accounting years (Granato, 2013).

Regional analyses are useful for developing planninglevel estimates, but regional values may not capture local variations in precipitation characteristics. Although the ecoregion-median is theoretically the best estimate for any randomly selected location in an ecoregion, knowledge about local conditions can be applied to improve such estimates. In California and surrounding areas where precipitation characteristics change substantially over short distances and especially at high elevations, moving from a level 1 to a level 2 analysis on the basis of knowledge of local patterns can reduce the uncertainty of regional estimates. In the SELDM manual (Granato, 2013), the use of statistics from the database application for nearby sites is described as a level 2 analysis to distinguish it from an analysis based on regional values; however, the phrase "level 2" should not be confused with the description of "level III" ecoregions. The ecoregions in this area of the country are large - ranging from about 7,630 to 121,000 square miles (table 2) - and the precipitation-station density in some ecoregions is low, ranging from 293 to about 4,320 square miles per station (table 3 ).

Because the regional values provide only planning-level estimates, expert judgement was used to select National Oceanic and Atmospheric Administration hourly-precipitation monitoring stations to calculate representative precipitation statistics for individual TMDL areas in California (Granato and Friesz, 2021). The precipitation statistics used for the analyses were the medians of statistics from the selected hourly precipitation monitoring stations within or adjacent to each area (table 4). Although there are 84 TMDLs in the CalTrans permit (California Department of Transportation, 2016; California State Water Resources Control Board, 2017), table 4 includes 31 sets of precipitation statistics because TMDLs for multiple constituents are colocated in highly developed basins, and because multiple TMDLs are clustered in areas represented by the same hourly precipitation monitoring stations (Granato and Friesz, 2021). The medians were selected because this method has been shown to produce robust local estimates of synoptic-precipitation statistics (Risley and Granato, 2014; Stonewall and others, 2019; Weaver and others, 2019). Departures from the 
Table 4. Synoptic precipitation statistics representing the median of selected-station values used for annual-yield analyses in California with the Stochastic Empirical Loading and Dilution Model (SELDM).

[Synoptic precipitation statistics were calculated by using the definition of a runoff generating event with a minimum interevent time of 6 hours and a minimum precipitation volume of 0.1 inch of liquid precipitation; the statistics are the medians of statistics from selected National Oceanic and Atmospheric Administration (NOAA) hourly precipitation data stations with at least 25 years of data from 1965 to 2006 (Granato, 2010a) that are located within or near the area of interest. Hourly precipitation data stations were selected to represent the hydrology of different total maximum daily load focus areas in California. Level III ecoregions are defined by the U.S. Environmental Protection Agency (EPA; Omernik and others, 2003) and listed in table 2. The analysis index number is the sequence number key HighwayAnalysis_ID in table tblHighwayAnalysis in the SELDM application; the 100-percent impervious simulations are in the 4,000 series and the 60-percent impervious simulations are in the 6,000 series of analyses (Granato and Friesz, 2021). Delta is the time between storm event midpoints. in/yr, inch per year; in, inch; hr, hour]

\begin{tabular}{|c|c|c|c|c|c|c|c|}
\hline \multicolumn{2}{|c|}{ Index number } & \multicolumn{5}{|c|}{ Medians of long-term average statistics from measured data } & \multirow[b]{2}{*}{$\begin{array}{l}\text { Number of } \\
\text { NOAA stations }\end{array}$} \\
\hline $\begin{array}{l}\text { EPA level III } \\
\text { ecoregion }\end{array}$ & $\begin{array}{c}\text { Analysis } \\
\text { index number }\end{array}$ & $\begin{array}{c}\text { Runoff- } \\
\text { generating } \\
\text { events per year }\end{array}$ & $\begin{array}{c}\text { Annual runoff- } \\
\text { generating } \\
\text { precipitation } \\
\text { (in/yr) }\end{array}$ & $\begin{array}{l}\text { Event volume } \\
\quad \text { (in.) }\end{array}$ & $\begin{array}{l}\text { Event duration } \\
\text { (hr) }\end{array}$ & $\begin{array}{c}\text { Delta } \\
\text { (hr) }\end{array}$ & \\
\hline 1 & 6 & 30 & 33.95 & 1.06 & 10.86 & 292 & 2 \\
\hline 1 & 24 & 50 & 51.04 & 1.01 & 12.57 & 162 & 2 \\
\hline 1 & 25 & 43 & 45.01 & 1.07 & 13.13 & 188 & 9 \\
\hline 1 & 26 & 36 & 40.83 & 1.04 & 12.71 & 198 & 3 \\
\hline 1 & 27 & 34 & 39.61 & 1.09 & 15.42 & 224 & 4 \\
\hline 1 & 28 & 33 & 34.20 & 1.14 & 13.06 & 219 & 3 \\
\hline 1 & 29 & 36 & 29.71 & 0.85 & 12.84 & 223 & 2 \\
\hline 1 & 30 & 35 & 31.96 & 0.93 & 13.36 & 227 & 3 \\
\hline 1 & 31 & 30 & 40.66 & 1.25 & 13.43 & 271 & 3 \\
\hline 5 & 4 & 31 & 23.46 & 0.76 & 11.18 & 272 & 1 \\
\hline 6 & 1 & 18 & 9.51 & 0.51 & 9.30 & 478 & 2 \\
\hline 6 & 2 & 18 & 15.10 & 0.84 & 9.10 & 470 & 2 \\
\hline 6 & 3 & 17 & 9.51 & 0.58 & 7.72 & 525 & 4 \\
\hline 6 & 7 & 18 & 15.71 & 0.88 & 10.28 & 449 & 3 \\
\hline 6 & 8 & 27 & 27.12 & 1.03 & 10.31 & 293 & 5 \\
\hline 6 & 9 & 28 & 19.60 & 0.68 & 10.61 & 288 & 10 \\
\hline 6 & 10 & 26 & 27.12 & 1.05 & 11.53 & 293 & 3 \\
\hline 6 & 11 & 26 & 23.71 & 0.92 & 11.12 & 315 & 4 \\
\hline 6 & 13 & 16 & 18.93 & 1.15 & 10.20 & 529 & 6 \\
\hline 6 & 14 & 17 & 17.09 & 0.99 & 12.17 & 492 & 9 \\
\hline 6 & 16 & 16 & 14.31 & 0.93 & 11.19 & 516 & 7 \\
\hline 6 & 17 & 16 & 15.36 & 0.93 & 11.74 & 515 & 21 \\
\hline 6 & 18 & 16 & 10.01 & 0.68 & 8.77 & 539 & 5 \\
\hline 7 & 12 & 28 & 15.97 & 0.58 & 12.42 & 308 & 4 \\
\hline 8 & 15 & 17 & 23.59 & 1.38 & 11.67 & 466 & 1 \\
\hline 9 & 19 & 21 & 6.89 & 0.33 & 7.96 & 428 & 1 \\
\hline 78 & 20 & 31 & 19.00 & 0.60 & 10.30 & 271 & 4 \\
\hline 78 & 21 & 29 & 23.29 & 0.66 & 10.93 & 247 & 3 \\
\hline 78 & 22 & 36 & 30.88 & 0.87 & 13.14 & 233 & 14 \\
\hline 78 & 23 & 36 & 38.14 & 0.93 & 13.75 & 228 & 5 \\
\hline 81 & 5 & 4 & 2.42 & 0.54 & 7.18 & 2017 & 1 \\
\hline
\end{tabular}


median-ecoregion values for precipitation statistics in this area of the country can be substantial (fig. 2). The regional values provide insights for interpretation and comparison, but the local estimates provide statistics needed for individual sitespecific analyses in areas of the country where precipitation characteristics vary substantially over short distances. Such variations commonly occur where mountains cause orographic effects (Risley and Granato, 2014; Weaver and others, 2019).

Runoff coefficients are the transfer functions that translate precipitation volumes into runoff volumes (Granato 2010a, 2013). In SELDM, runoff coefficients are simulated stochastically by using the average, standard deviation, and skew of runoff coefficients that are either entered by the user or are calculated on the basis of the type of site (highway or nonhighway) and imperviousness of the site. In this study, two impervious fractions were simulated - a value of 1.0 (100 percent impervious) and 0.6 (60 percent impervious). The value of 1.0 was selected to simulate runoff from paved areas and the value of 0.6 to simulate an area representing a highway corridor with unpaved median and shoulders. The average, standard deviation, and skew of the runoff coefficients used to simulate runoff from the completely impervious highway areas were $0.785,0.1917$, and -1.19 , respectively. The average, standard deviation, and skew of the runoff coefficients used to simulate runoff from the 60-percent impervious areas were $0.483,0.20662$, and 0.138 , respectively. These statistics were calculated from imperviousness by using the SELDM highway site equations (Granato 2010a, 2013).

For a series of urban runoff simulations, the SELDM nonhighway equations (Granato 2010a, 2013) were used to calculate runoff coefficient statistics from completely (100 percent) impervious areas. The average, standard deviation, and skew of these runoff coefficients are $0.769,0.114$, and -0.51 , respectively. The higher average for the highway sites may reflect the effect of random sampling or may be the result of engineering design objectives to rapidly drain runoff from the roadway and efficiently convey runoff from the road to stormwater discharge locations to maintain safe driving conditions (Brown and others, 2009).
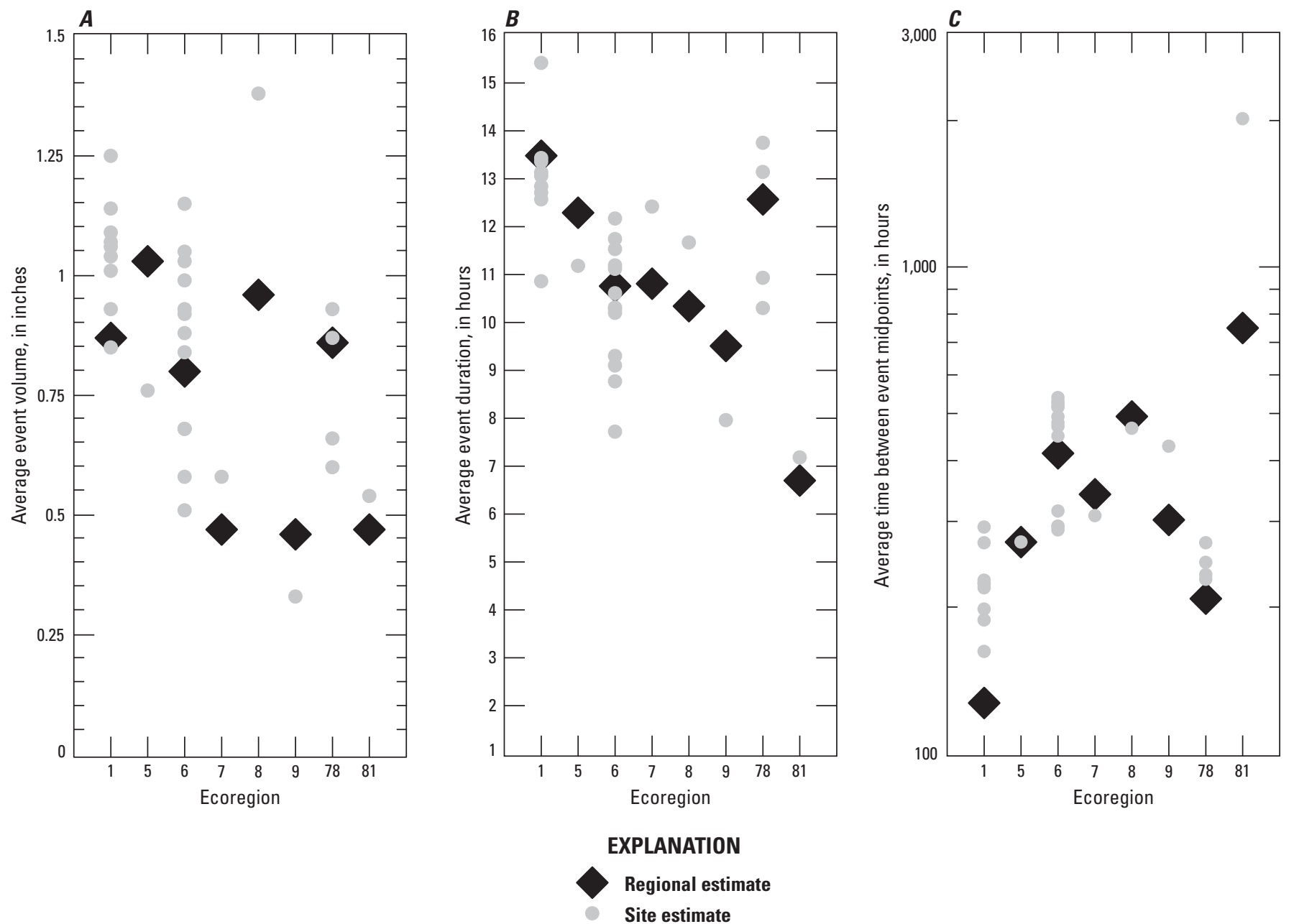

Figure 2. Graphs showing comparisons of precipitation statistics for selected sites and the medians of statistics for all hourly precipitation data stations used for annual-yield analyses in California with the Stochastic Empirical Loading and Dilution Model. $A$, Average event volume; $B$, Average event duration; and $C$, Average time between event midpoints. 
Both of these average runoff coefficient values are lower than the commonly used values, which can be as high as 0.96 for completely impervious areas; research shows that commonly used runoff coefficient values are biased high because of the assumptions and methods used to estimate runoff volumes, and because runoff coefficients used for drainage design include a margin of safety (Granato, 2010a, 2013). Although the stochastic runoff-generation algorithms in SELDM produce many events with runoff coefficients at or near a value of 1 , a substantial number of events will show the precipitation losses evident in high-quality runoff monitoring datasets (Granato, 2010a).

SELDM uses a random-seed management algorithm to ensure that each runoff quality analysis will be reproducible (Granato, 2013). In SELDM (and other programs that use Monte Carlo methods), the (pseudo) random-number generators use an initial set of values known as the random seeds. Each SELDM analysis uses a master-seed identification number (ID) to select one of the 11,111 random-seed pairs in the seed table of the database application. Changing the seed values shuffles the random combinations of flows, concentrations, and treatment efficiencies, and therefore the storm and annual loads among the simulated storm events. SELDM is designed to generate from about 25 years of record (in humid areas) to about 60 years of record (in extremely arid areas) to produce enough events to allow for convergence toward input statistics without vastly exceeding the record lengths used to calculate precipitation and flow statistics. However, Monte Carlo methods can produce events that greatly exceed the sample probability in the simulated record. Although a 100-, $500-$, or 1,000-year precipitation event would not be expected during a typical simulation period, such events can occur randomly, and the presence of such events can greatly inflate loads, especially if large events are randomly paired with large runoff coefficients and high concentrations. Granato and Jones (2017) did a seven-seed sensitivity analysis and focused on the median of highway runoff loads produced. In the current study, a 111-seed sensitivity analysis was done by using precipitation statistics from a humid area (ecoregion 1, the Coast Range) and an arid area (ecoregion 5, the Sierra Nevada). The focus of this random-seed analysis was on the long-term average annual precipitation, runoff, and BMP discharge volumes produced. Although all three of these hydrologic variables were evaluated, the final master-seed selection was based on the runoff volume because this was the value used to calculate the yields for all the constituents of concern.

\section{Runoff Quality Analysis}

Statistics were calculated for 53 water-quality properties and constituents of concern (table 5) in California (California State Water Resources Control Board, 2017), and these statistics were used to simulate long-term populations of runoff events. For most constituents, statistics from sites with seven or more storm events were included in the analysis to determine the median values in tables 6 and 7. Highway runoff quality statistics were calculated by using version $1.1 .0 \mathrm{a}$ of the HRDB (Granato and Friesz, 2021). Highway runoff quality statistics from sites with fewer events were used for the pesticides and polychlorinated biphenyls (PCBs). National urbanrunoff quality statistics for commonly measured properties and constituents were calculated by using version 1.2.0 of the Best Management Practices Statistical Estimator (BMPSE), which includes urban runoff data from the December 2019 version of the International BMP database (Granato, 2021a). Statistics for urban runoff quality constituents that are not commonly measured were calculated by using version 4.02 of the National Stormwater Quality Database (NSQD; International Stormwater Best Management Practices Database, 2015). Statistics for unfiltered PCBs (Gilbreath and others, 2019, unfiltered Dieldrin (Masoner and others, 2019), and unfiltered methylmercury (Masoner and others, 2019) in urban runoff were estimated by using literature values because data for these constituents were not available in the BMPSE or the NSQD. Simulations were run by using highway runoff quality (table 6) and urban runoff quality (table 7) statistics.

Highway and urban runoff quality datasets contain many values - commonly known as censored values - that are measured below one or more detection limits. The HRDB uses the robust regression-on-order statistics (ROS) method to estimate statistics for datasets that include censored values (Helsel and Hirsch, 2002; Granato and Cazenas, 2009). The ROS algorithms from the HRDB were added to the BMPSE to calculate urban runoff statistics (Granato, 2021a). The NSQD does not include the methods necessary to do a ROS analysis, so ROS methods were applied manually to the data from the NSQD and to literature values to estimate urban runoff statistics for those constituents.

All concentrations were simulated as random variables by using the frequency-factor method with the average, standard deviation, and skew of the transformed (logarithmic) or untransformed (arithmetic) values (Granato, 2013). All the constituents except $\mathrm{pH}$ were simulated by using statistics for the logarithms of data (tables 6 and 7). Concentrations of properties and constituents of highway and urban runoff commonly are analyzed and simulated by using the logarithms of the data because concentration data vary by orders of magnitude and are bounded by zero (Athayde and others, 1983; Di Toro, 1984; Driscoll, Palhegyi, and others, 1989; Driscoll, Shelley, and others, 1989, 1990; Van Buren and others, 1997; Novotny, 2004; Kayhanian and others, 2007; Granato and Cazenas, 2009; National Research Council, 2009; Smith and Granato, 2010; Granato, 2013; Smith and others, 2018; Weaver and others, 2019). However, $\mathrm{pH}$ is defined as the negative logarithm of the hydronium ion concentration (Hem, 1992); the hydronium ion may be simulated by using the logarithms of data, but $\mathrm{pH}$ must be simulated in arithmetic space. 
Table 5. Runoff quality constituents used to simulate highway and urban runoff quality in selected areas of California with counts of the number of highway and urban runoff sites and the best management practices treatment analysis method.

[Pcode is the water-quality parameter code denoted by the letter $\mathrm{p}$ and the five-digit identification number from the U.S. Geological Survey (2021) National Water Information System (NWIS). Name is the constituent name in NWIS. Fraction is the sampled fraction (filtered water or unfiltered [whole] water); BMP (best management practice) is the treatment estimate, as follows: C, water- quality-category median estimated by Granato and others (2021, table 7); M, estimated from measured data by Granato and others (2021, table 1.1); and S, water-quality-treatment estimate from a similar constituent. HN is the number of highway sites in the Highway-Runoff Database (Granato, 2019) used to calculate constituent concentration statistics. UN is the number of urban sites in the Best Management Practices Statistical Estimator (Granato, 2021a) or the National Stormwater Quality Database (International Stormwater Best Management Practices Database, 2015) used to calculate constituent concentration statistics. e; estimated from a similar constituent; L, literature value estimate from Gilbreath and others (2019) or Masoner and others (2019); PAHs, polycyclic aromatic hydrocarbons; PCBs, polychlorinated biphenyls; EPA, U.S. Environmental Protection Agency; CEDEN, California Environmental Data Exchange Network]

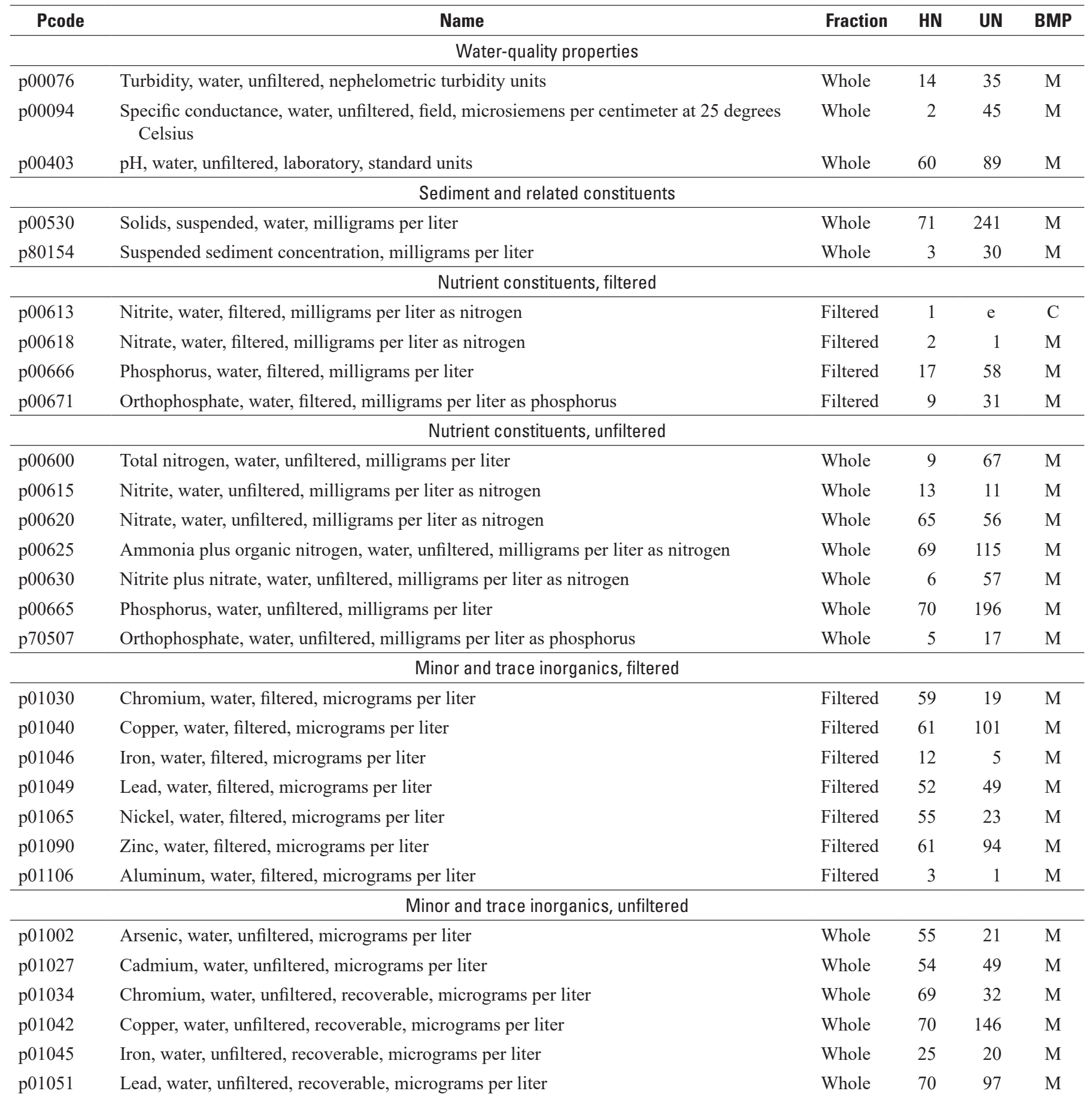




\section{Assessing Long-Term Annual Yields of Runoff in California with the Stochastic Empirical Loading and Dilution Model}

Table 5. Runoff quality constituents used to simulate highway and urban runoff quality in selected areas of California with counts of the number of highway and urban runoff sites and the best management practices treatment analysis method.-Continued

[Pcode is the water-quality parameter code denoted by the letter p and the five-digit identification number from the U.S. Geological Survey (2021) National Water Information System (NWIS). Name is the constituent name in NWIS. Fraction is the sampled fraction (filtered water or unfiltered [whole] water); BMP (best management practice) is the treatment estimate, as follows: C, water- quality-category median estimated by Granato and others (2021, table 7); M, estimated from measured data by Granato and others (2021, table 1.1); and S, water-quality-treatment estimate from a similar constituent. HN is the number of highway sites in the Highway-Runoff Database (Granato, 2019) used to calculate constituent concentration statistics. UN is the number of urban sites in the Best Management Practices Statistical Estimator (Granato, 2021a) or the National Stormwater Quality Database (International Stormwater Best Management Practices Database, 2015) used to calculate constituent concentration statistics. e; estimated from a similar constituent; L, literature value estimate from Gilbreath and others (2019) or Masoner and others (2019); PAHs, polycyclic aromatic hydrocarbons; PCBs, polychlorinated biphenyls; EPA, U.S. Environmental Protection Agency; CEDEN, California Environmental Data Exchange Network]

\begin{tabular}{|c|c|c|c|c|c|}
\hline Pcode & Name & Fraction & HN & UN & BMP \\
\hline \multicolumn{6}{|c|}{ Minor and trace inorganics, unfiltered-Continued } \\
\hline p01067 & Nickel, water, unfiltered, recoverable, micrograms per liter & Whole & 59 & 36 & M \\
\hline p01092 & Zinc, water, unfiltered, recoverable, micrograms per liter & Whole & 70 & 169 & M \\
\hline p01104 & Aluminum, water, unfiltered, recoverable, micrograms per liter & Whole & 13 & 4 & M \\
\hline p71900 & Mercury, water, unfiltered, recoverable, micrograms per liter & Whole & 4 & 6 & $\mathrm{~S}$ \\
\hline \multicolumn{6}{|c|}{ Organic constituents } \\
\hline p00310 & $\begin{array}{l}\text { Biochemical oxygen demand, water, unfiltered, } 5 \text { days at } 20 \text { degrees Celsius, milligrams } \\
\text { per liter }\end{array}$ & Whole & 10 & 3 & M \\
\hline p00680 & Organic carbon, water, unfiltered, milligrams per liter & Whole & 54 & 46 & M \\
\hline p75984mb & PCBs, water, unfiltered, recoverable, nanograms per liter (sum of homologs) & Whole & 1 & e & $\mathrm{S}$ \\
\hline p75984mc & $\begin{array}{l}\text { PCBs, water, unfiltered, recoverable, nanograms per liter (sum of congeners, CalTrans in } \\
\text { CEDEN) }\end{array}$ & Whole & 4 & $\mathrm{~L}$ & $\mathrm{~S}$ \\
\hline pXXX05 & PAHs EPA 8310, water, unfiltered, micrograms per liter, (sum of 16 PAHs not censored) & Whole & 8 & 8 & M \\
\hline pXXX06 & PAHs, water, unfiltered, micrograms per liter, (sum of PAHs, CalTrans in CEDEN) & Whole & 2 & e & $\mathrm{S}$ \\
\hline \multicolumn{6}{|c|}{ Biological constituents } \\
\hline p31507 & Total coliform, completed test, water, most probable number per 100 milliliters & Whole & 2 & 29 & M \\
\hline p31616 & Fecal coliform, M-FC MF (0.45-micrometer) method, water, colonies per 100 milliliters & Whole & 7 & 8 & M \\
\hline p50468 & $\begin{array}{l}\text { Escherichia coli, Colilert Quantitray method, water, most probable number per } 100 \text { mil- } \\
\text { liliters }\end{array}$ & Whole & 5 & 11 & M \\
\hline p00900 & Hardness, water, unfiltered, milligrams per liter as calcium carbonate & Whole & 69 & 12 & M \\
\hline p00940 & Chloride, water, filtered, milligrams per liter & Filtered & 5 & 58 & M \\
\hline p70300 & $\begin{array}{l}\text { Solids, total dissolved: Residue, water, filtered, dried at } 180 \text { degrees Celsius, milligrams } \\
\text { per liter }\end{array}$ & Filtered & 9 & $\mathrm{e}$ & $\mathrm{S}$ \\
\hline
\end{tabular}


Table 6. Statistics used to simulate highway-runoff quality in California with the Stochastic Empirical Loading and Dilution Model (SELDM).

[Data are from studies sponsored by the department of transportation for State(s) indicated (CA, California; MA, Massachusetts; NV, Nevada; OR, Oregon; WA, Washington). Pcode, water-quality parameter code denoted by the letter $\mathrm{p}$ and the five-digit identification number from the U.S. Geological Survey (2021) National Water Information System (NWIS); log, (common) logarithms of data; percentage not skewed, percentage of sites with a skew value that is not significantly different from 0 at the 95-percent confidence interval (Interagency Advisory Committee on Water Data, 1982); Spearman's rho, rank correlation coefficient; avg-SD, correlation between the average and standard deviation; avg-AADT, correlation between the average concentration and the average annual daily traffic; NPNS, nonparametric Nash-Sutcliffe efficiency (eq. 6 in Legates and McCabe, 1999 with the median replacing the mean), indicating the predictive power of the regression relation to estimate the concentration from the logarithms of average annual daily traffic (a positive NPNS value indicates the predictive strength of the regression, and a value less than or equal to zero indicates that the observed median is a better predictor than the regression equation); source (Granato and Friesz, 2021);-, insufficient data to calculate statistic]

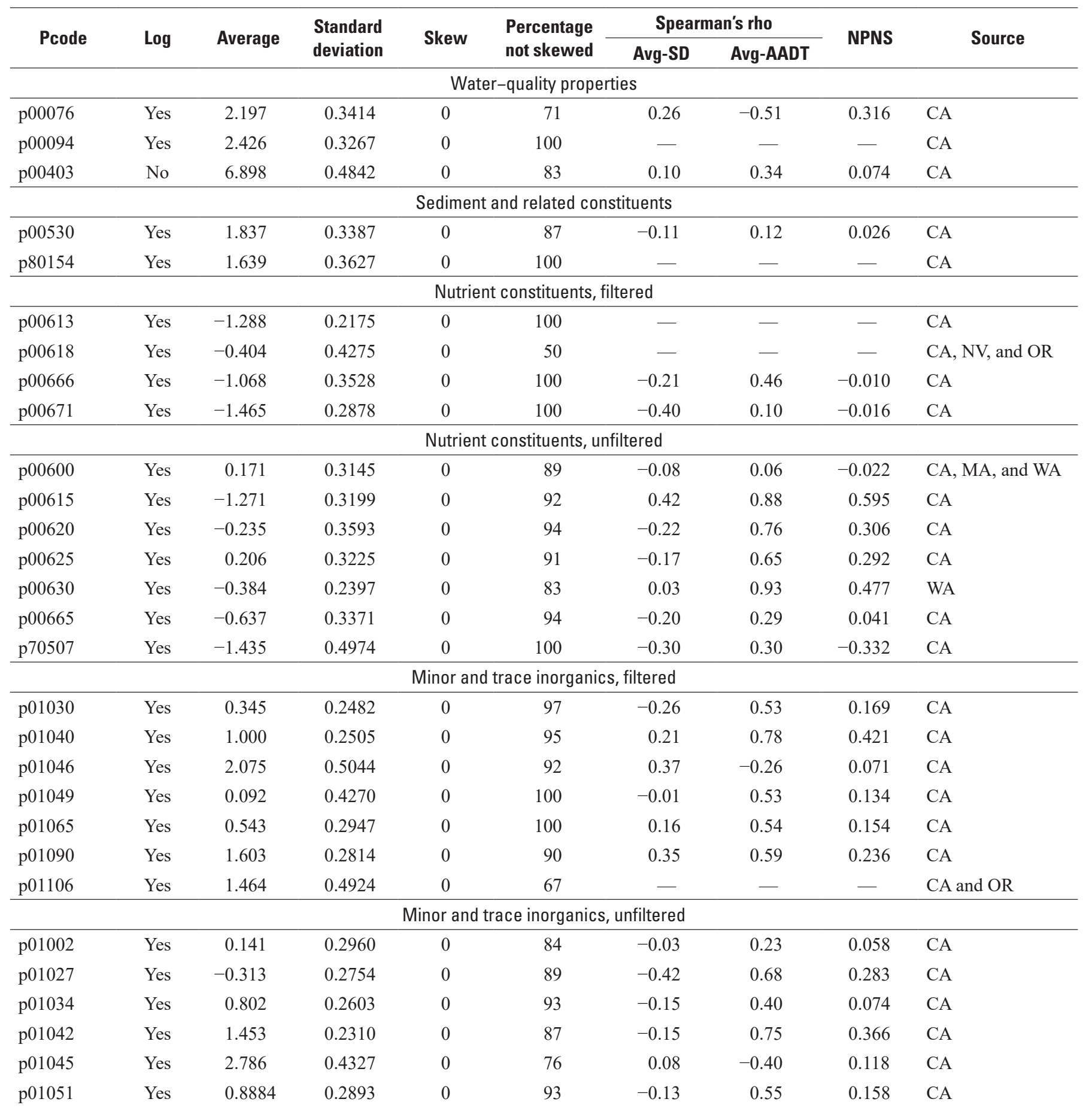


Table 6. Statistics used to simulate highway-runoff quality in California with the Stochastic Empirical Loading and Dilution Model (SELDM).-Continued

[Data are from studies sponsored by the department of transportation for State(s) indicated (CA, California; MA, Massachusetts; NV, Nevada; OR, Oregon; WA, Washington). Pcode, water-quality parameter code denoted by the letter p and the five-digit identification number from the U.S. Geological Survey (2021) National Water Information System (NWIS); log, (common) logarithms of data; percentage not skewed, percentage of sites with a skew value that is not significantly different from 0 at the 95-percent confidence interval (Interagency Advisory Committee on Water Data, 1982); Spearman's rho, rank correlation coefficient; avg-SD, correlation between the average and standard deviation; avg-AADT, correlation between the average concentration and the average annual daily traffic; NPNS, nonparametric Nash-Sutcliffe efficiency (eq. 6 in Legates and McCabe, 1999 with the median replacing the mean), indicating the predictive power of the regression relation to estimate the concentration from the logarithms of average annual daily traffic (a positive NPNS value indicates the predictive strength of the regression, and a value less than or equal to zero indicates that the observed median is a better predictor than the regression equation); source (Granato and Friesz, 2021);- - insufficient data to calculate statistic]

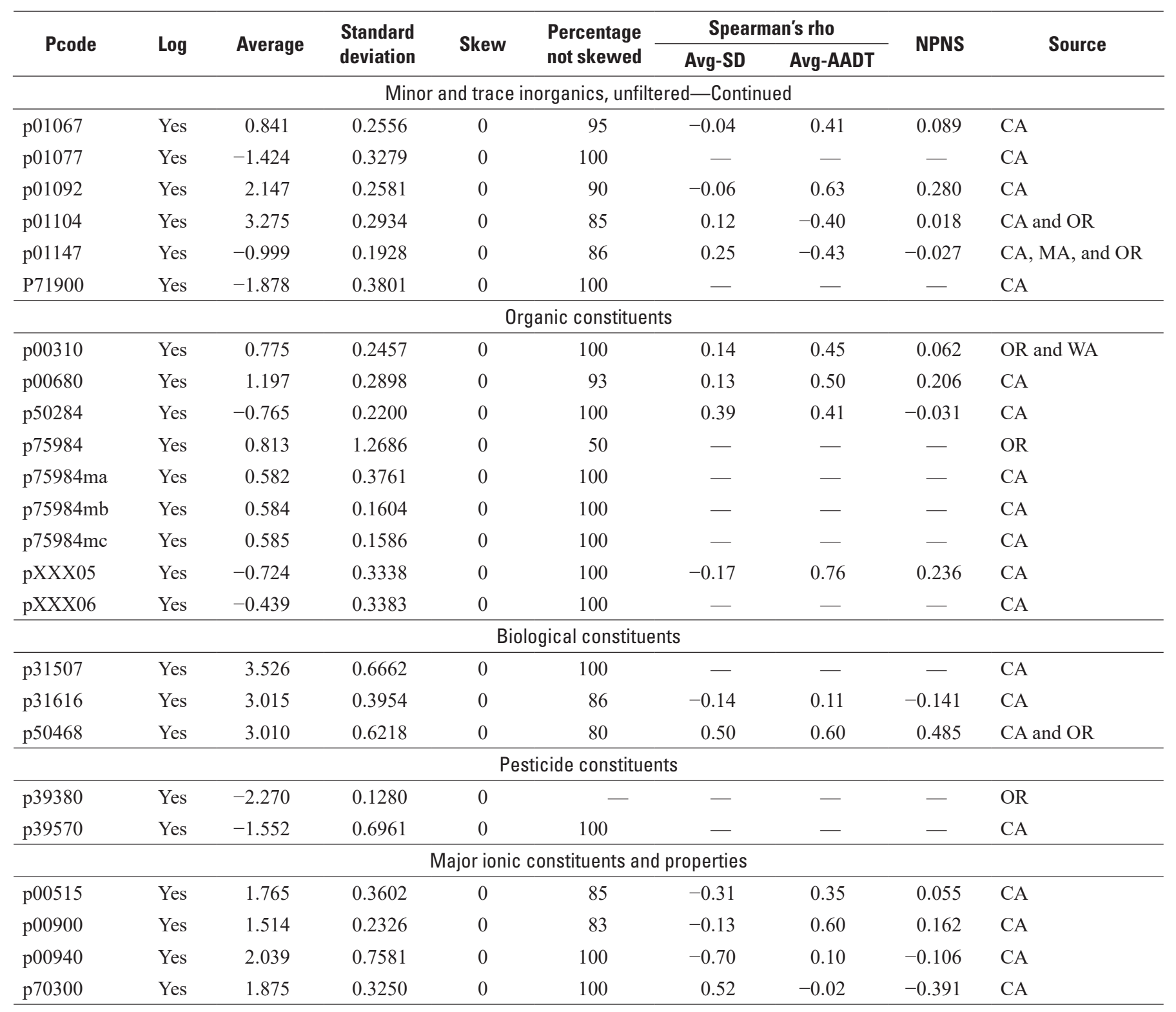


Table 7. National urban-runoff quality statistics used to simulate urban-runoff quality in California with the Stochastic Empirical Loading and Dilution Model (SELDM).

[Pcode, water-quality parameter code denoted by the letter $\mathrm{p}$ and the five-digit identification number from the U.S. Geological Survey (2021) National Water Information System (NWIS); log, (common) logarithms of data; percentage not skewed, percentage of sites with a skew value that is not significantly different from zero at the 95-percent confidence interval (Interagency Advisory Committee on Water Data, 1982); BMPSE, Best Management Practices Statistical Estimator (Granato, 2021a); NSQD, National Stormwater Quality Database (International Stormwater Best Management Practices Database, 2015); SCVURPPP, Santa Clara Valley Urban Runoff Pollution Prevention Program; - , insufficient data to calculate statistic]

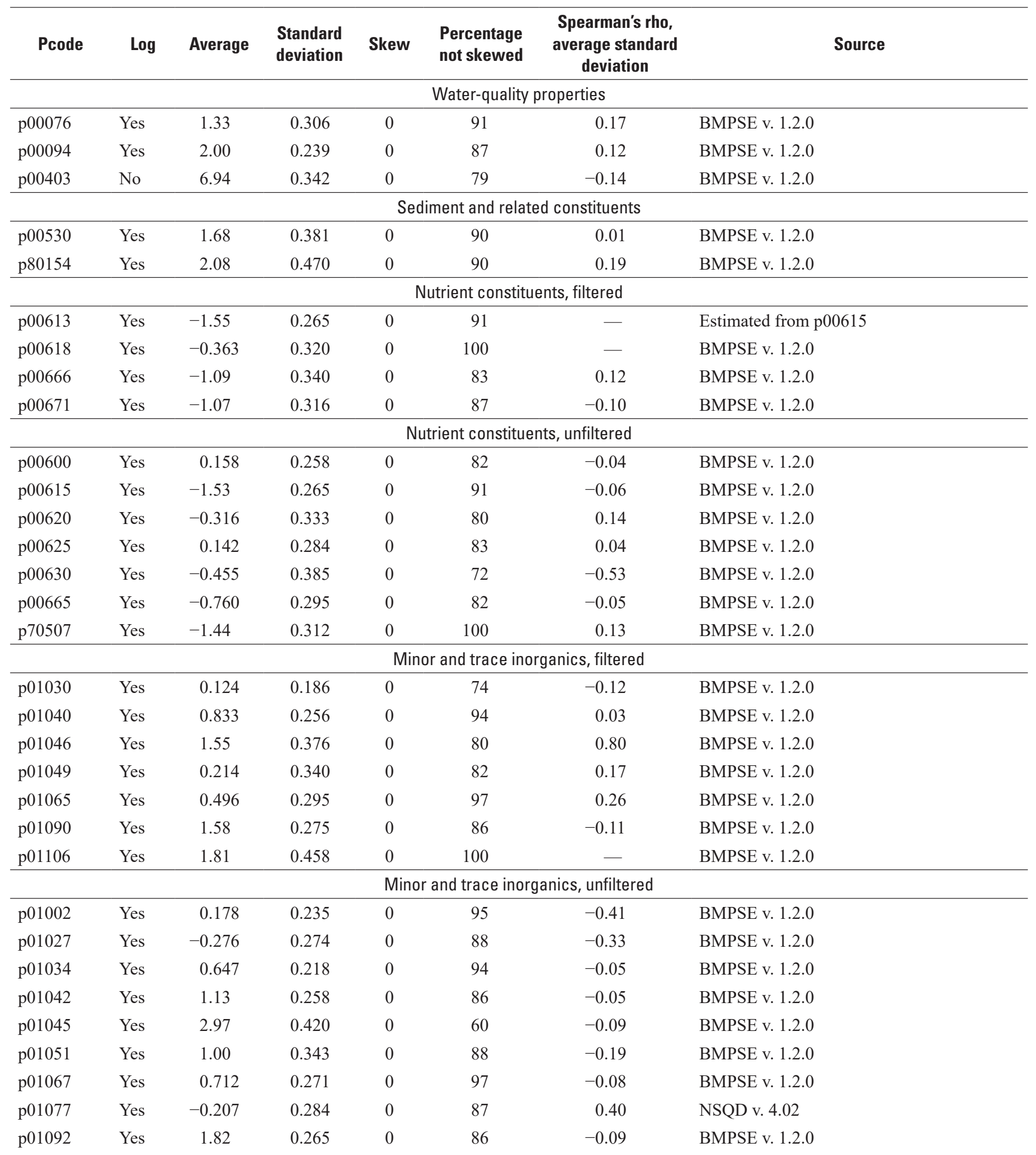


Table 7. National urban-runoff quality statistics used to simulate urban-runoff quality in California with the Stochastic Empirical Loading and Dilution Model (SELDM).-Continued

[Pcode, water-quality parameter code denoted by the letter $\mathrm{p}$ and the five-digit identification number from the U.S. Geological Survey (2021) National Water Information System (NWIS); log, (common) logarithms of data; percentage not skewed, percentage of sites with a skew value that is not significantly different from zero at the 95-percent confidence interval (Interagency Advisory Committee on Water Data, 1982); BMPSE, Best Management Practices Statistical Estimator (Granato, 2021a); NSQD, National Stormwater Quality Database (International Stormwater Best Management Practices Database, 2015); SCVURPPP, Santa Clara Valley Urban Runoff Pollution Prevention Program; - , insufficient data to calculate statistic]

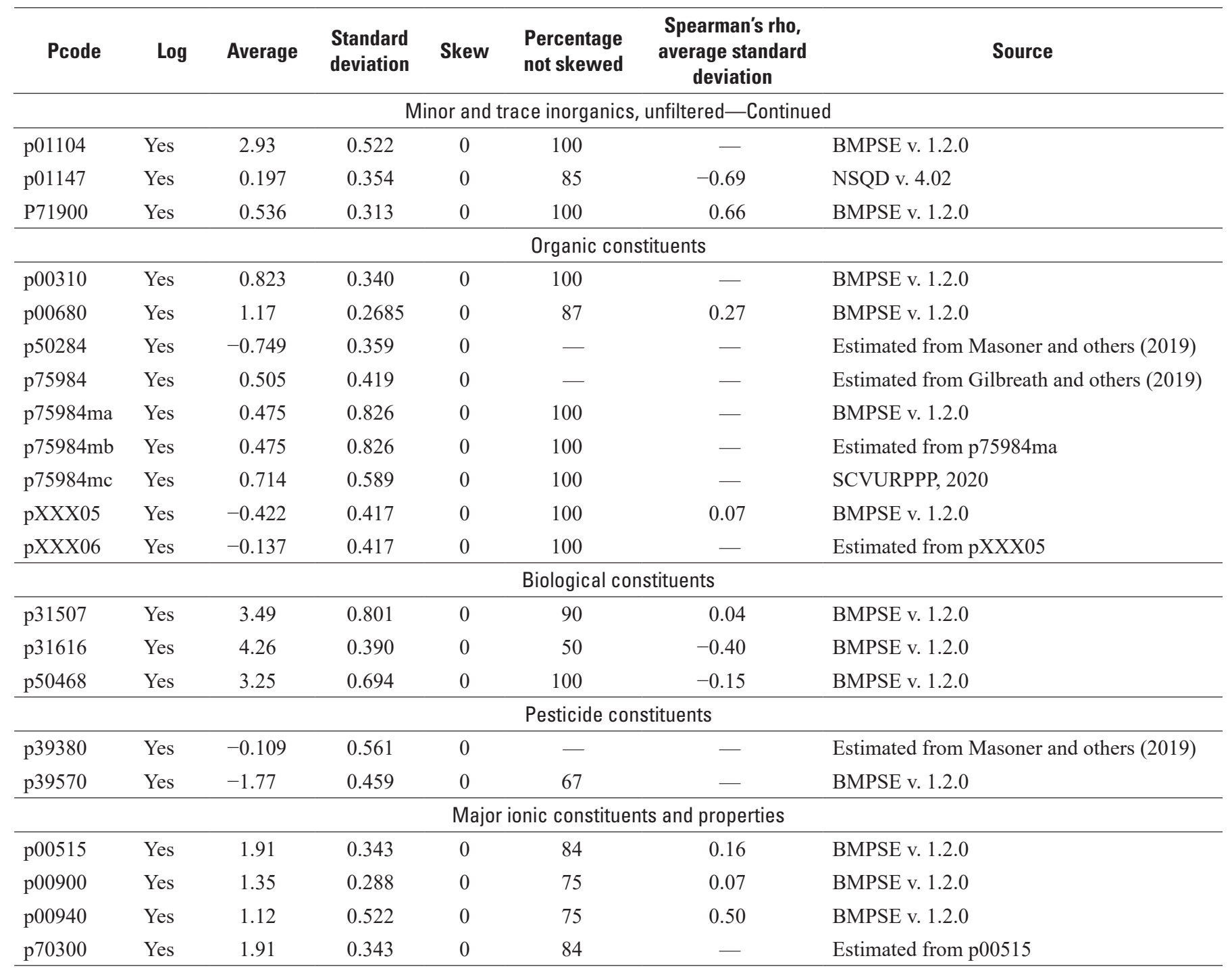


Concentrations of highway and urban runoff were simulated by using a skew value of 0 . This value was selected because the percentage of datasets with skew values that were not significantly different from 0 at the 95 -percent confidence interval was large. For highway runoff, the percentage of datasets with calculated skews that were not significantly different from zero ranged from 50 to 100 percent with an average of 91 percent (table 6). For urban runoff, the percentage of datasets with calculated skews that were not significantly different from zero ranged from 50 to 100 percent with an average of 88 percent (table 7). Skew values of 0 were used because most constituents could be characterized as lognormal (or normal for $\mathrm{pH}$ ), and because use of a skew equal to 0 would reduce the risks for generating improbable extreme outliers in the simulated highway and urban runoff concentration populations (Risley and Granato, 2014).

SELDM simulates individual event loads and loads for annual load accounting years for constituents in units of mass per unit volume (for example, milligrams per liter; Granato, 2013). For $\mathrm{pH}$, it calculates loads of the hydronium ion. For other constituents that are not measured with units of mass per unit volume, including turbidity, specific conductance, and measures of bacterial concentrations, SELDM calculates flowweighted loading values that are the product of water-quality measurement statistics and flow but are not actual mass values. However, these flow-weighted values can be used to estimate loadings to receiving waters and the potential effectiveness of BMPs to reduce flows and loading values (Granato, 2013).

Rank correlation analysis using Spearman's rho was used to guide selection of runoff water-quality statistics for analysis (table 6). Spearman's rho is a robust method of analysis that indicates the strength of relations between variables without the assumption that the relation is linear; rank correlation is not affected by transforming data to or from logarithmic space (Helsel and Hirsch, 2002). Correlation coefficients were calculated if data were available from five or more sites because this is the minimum number of data points needed to quantify the correlation coefficients and determine their confidence intervals, which become more narrow with increasing sample size (Abdel-Megeed, 1984; Caruso and Cliff, 1997). Rank correlation analyses were used to evaluate the crosscorrelation between the average and standard deviation of $\mathrm{pH}$ and the logarithms of concentrations of other constituents to determine whether or not the values used for simulation could be selected independently. Rank correlation values for highway runoff constituents ranged from -0.7 to 0.52 with a median correlation of -0.06 (table 6 ). Rank correlation values for urban runoff constituents ranged from -0.69 to 0.8 with a median correlation of 0.01 (table 7). Apart from selenium in urban runoff, the strongest correlation coefficients were not significantly different from zero because they were associated with the smallest number of sites (tables 5-7; Caruso and Cliff, 1997).
Rank correlation coefficients also were calculated between the average annual daily traffic (AADT) at monitoring sites, the average of $\mathrm{pH}$, and the average of the logarithms of other constituents to assess the potential for developing explanatory equations (table 6). These rank correlation values ranged from -0.51 to 0.93 with a median of 0.45 . The number of highway sites in table 5 and the rho values in table 6 indicate that only about half the coefficients for five or more sites are statistically significant at the 95-percent confidence limits (Haan, 1977; Caruso and Cliff, 1997), and that only the nitrite constituent (p00615 and p00630) data would produce quantitative relations. Because some correlations were significant, the nonparametric Nash Sutcliffe efficiency (NPNS) statistic (eq. 6 in Legates and McCabe, 1999 with the median replacing the mean) was calculated to compare the predictive power of the logarithms of AADT for estimating constituent concentrations (table 6). The rank correlation coefficients and NPNS values generally indicate that AADT is not a strong predictor for constituent concentrations at study sites for most constituents. The best potential relation (and equation) for nitrite ( $\mathrm{p} 00615$ ) would explain only about 60 percent of the variation in concentration as a function of AADT; the percentages for most other relations were far worse (table 6).

The application of predictive equations from monitoring sites to unmonitored sites in TMDL watersheds also is complicated by variations in AADT within TMDL watersheds and uncertainties in short-term AADT measurements. Point AADT measurements on a road may not represent traffic volumes at other points along the same roadway and do not represent traffic volumes along other roads within the watershed. For example, CalTrans reports AADT values from a statewide network of 7,141 traffic monitoring stations (fig. 3; California Department of Transportation, 2018b). At 5,816 of these traffic monitoring stations, AADT values are reported as "Back" and "Ahead" of nominal monitoring locations, which indicates differences caused by changes in traffic to or from intersecting routes. The average absolute difference in AADT values at these sites is 7,150 vehicles per day (VPD), and the median is 2,400 VPD. Therefore, a measured AADT value for a single location would not be widely applicable in a TMDL watershed even along a single route. Furthermore, studies show that the uncertainty in AADT estimates from short-term monitoring stations commonly is on the order of plus or minus 20 percent and as high as plus or minus 50 percent for low AADT roads (less than 1,000 VPD) and that estimates are highly uncertain for all traffic volumes with measurement durations of less than a full day (Krile and others, 2015). Therefore, estimation of concentrations from AADT for application to TMDL estimates may be of limited value. Similarly, because of the limited power of AADT relations and the variations in AADT within TMDL watersheds, Lantin and others (2019) provided nationwide highway runoff statistics by AADT category but used the statistics from the lumped (all AADT) dataset to simulate long-term annual loads for TMDL analyses in different areas of the country. 


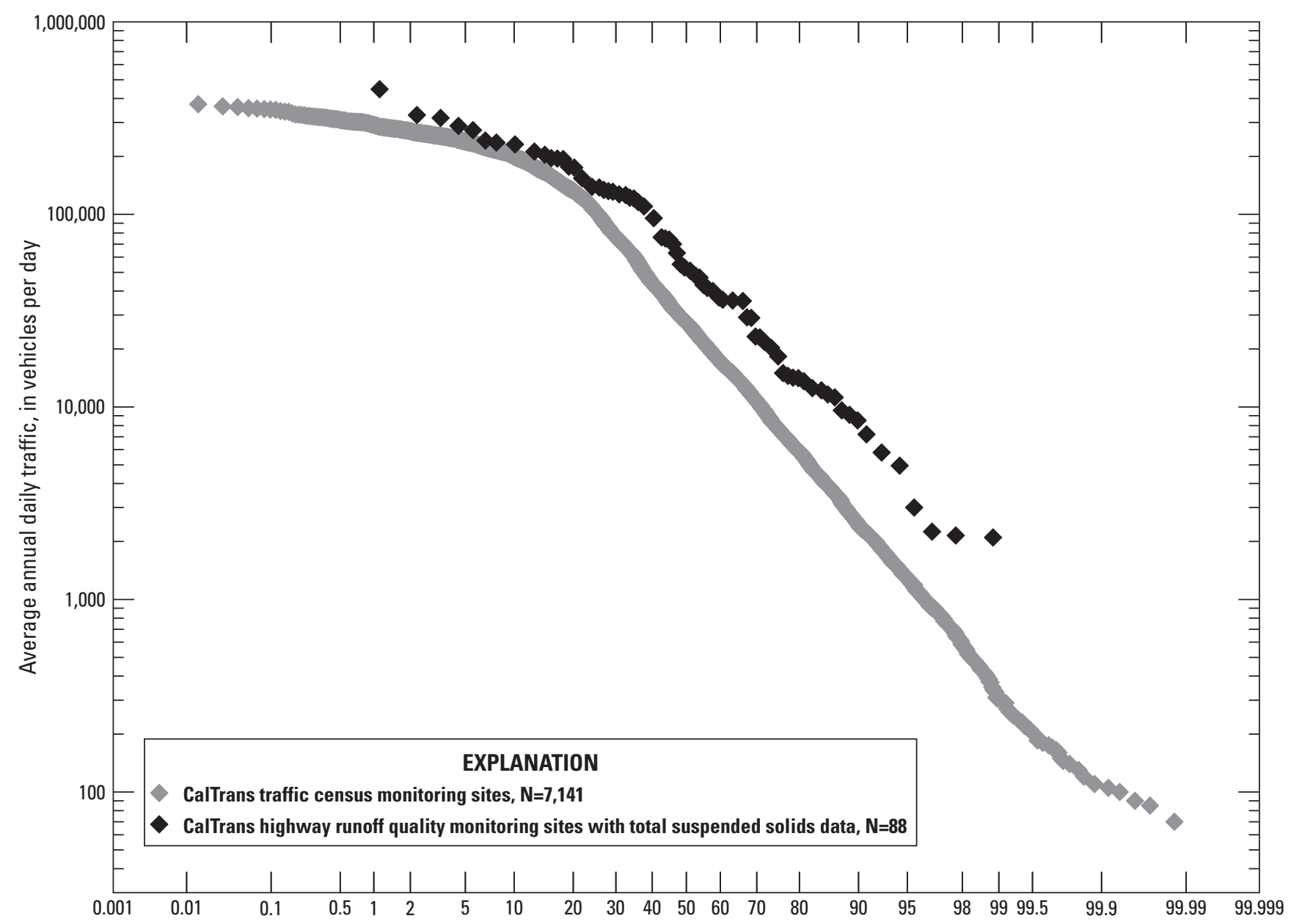

Percentage of sites with traffic counts greater than or equal to the given value

Figure 3. Scatter plot showing the annual average daily traffic counts at California Department of Transportation (CalTrans) traffic-census monitoring sites (California Department of Transportation, 2018b) and highway runoff monitoring sites (Granato and Friesz, 2021). N, number of sites.

\section{Runoff Treatment Analysis}

SELDM can be used to simulate three stormwatertreatment mechanisms, including runoff hydrograph extension, volume reduction, and water-quality treatment, by using a trapezoidal distribution with correlation to the inflow values (Granato 2013, 2014; Granato and Jones, 2014; Granato and others, 2021). Runoff hydrograph extension affects downstream flows, concentrations, and loads, but not the magnitudes of flows, concentrations, or loads discharged from the simulated site of interest. Therefore, the potential effects of runoff hydrograph extension were not examined in this study. The SELDM BMP module uses the trapezoidal distribution and the rank correlation with the associated highway or urban runoff variable to provide a stochastic transfer function to approximate the quantity and quality of BMP effluent given the associated inflow values in a simulation. SELDM also simulates the effect of the minimum irreducible concentration (MIC), which is the lowest expected BMP effluent concentration, by substituting a user-defined MIC value for BMP effluent concentrations that are less than the MIC.

SELDM uses rank correlation to preserve the structure of inflow and outflow data commonly found in BMP studies. Correlations between the ratios of outflow to inflow volumes and the magnitudes of inflows are positive because it would be difficult for BMPs built with commonly used designs to retain or infiltrate a large proportion of flow from a very large runoff event. As such, the positive correlations between inflow volumes and the outflow ratios calculated by Granato and others (2021) reduce the average effectiveness of volume reduction that would be simulated by using the ratios without correlation. Correlations between the concentration ratios and inflow concentrations are negative because BMP monitoring datasets indicate that BMPs are more effective for substantially reducing large inflow concentrations than small inflow concentrations. Therefore, the negative correlations between 
inflow concentrations and the outflow ratios increase the average effectiveness of concentration reductions that would be simulated by using the ratios without correlations.

In this study, runoff treatment was analyzed to examine the potential effects of volume reduction and water-quality treatment by stormwater BMPs on annual yields. SELDM generates a unique combination of treatment values for each event in the simulated time series by using the random numbers generated and the correlation with inflow values; it does not apply a universal treatment efficiency value to every runoff event (Granato, 2013). In SELDM, as in reality, outflow volumes and concentrations can exceed associated inflow values during some simulated events (Granato 2013, 2014; Granato and others, 2021). The load-reduction performance for each runoff event depends on the simulated volume reduction, the water-quality treatment, and the MIC. As for other variables, SELDM generates a random series of events rather than a time series, so it does not explicitly simulate seasonality or long-term changes in performance as BMPs age. Few BMP monitoring datasets have sufficient data to characterize either seasonality or the effects of aging (Taylor and others, 2014; Granato and others, 2021). However, calculating the ratio of the long-term average annual runoff load to the long-term average annual BMP discharge load would provide a longterm universal treatment efficiency estimate.

State departments of transportation commonly use many different types of BMPs suitable for the local hydrology, available areas in or near the right-of-way, other site constraints, and water-quality design objectives from site to site (Taylor and others, 2014; National Academies of Sciences, Engineering, and Medicine, 2015; California Department of Transportation, 2018a; Leisenring and others, 2020). As such, many water bodies that are adversely affected by stormwater discharges are likely to receive runoff from many types of BMPs. Even if one type of BMP is predominant in a basin of interest, research shows large variations in performance from site to site for every type of BMP (Granato, 2014; Taylor and others, 2014; Granato and others, 2021). Within BMP categories, Leisenring and others (2013) did not find that performance was quantitatively linked to physical design features. For example, Barrett and others (2004) found that outflow concentrations from grassy filter strips stabilized after about 16 feet, and that the performance was not affected by physical design features such as slope, vegetation type, or hydraulicresidence time. In a study of CalTrans BMP monitoring data, Barrett (2005) indicated that the inflow concentration was the primary predictor of outflow concentration for most BMP categories. Even if the performance of a specific BMP is known at one point in time, its performance will vary with age, maintenance, and many other factors (Taylor and others, 2014). Therefore, most simulations done for this project used a generic BMP calculated by using the median of statistics documented by Granato and others (2021).

CalTrans currently (2020) has a list of 14 categories of approved postconstruction BMPs (California Department of Transportation, 2019), but it also has experimental and legacy BMPs. To meet the requirements of its NPDES permit, CalTrans must increase the use of BMPs to treat highway and urban runoff in the State each year (California State Water Resources Control Board, 2017). During the 2017-18 fiscal year, CalTrans added about 682 new acres of treated area; about 14, 42, and 13 percent of these acres were treated by using biofilter (grass) strip (BI), biofilter (grass) swale (BS), and media-filter (MF) BMPs, respectively (California Department of Transportation, 2018a). About 30 percent of the new treatment area was treated with other types of BMPs.

The trapezoidal distribution of volume-reduction ratios for the generic, BI, BS, and MF BMPs are listed in table 8 . With the exception of the BS, there is some risk that the outflow will exceed the inflow volume. In theory, the outflow may exceed the inflow for a given event because of carryover from a previous event or because of groundwater exfiltration into the BMP. Water-quality statistics for the 53 water-quality constituents simulated in this study are the median values published by Granato and others (2021, table 1.1), which also are listed in the SELDM output-documentation file (*-Out.txt) for

Table 8. Median of selected stormflow volume-reduction statistics for the trapezoidal distribution and Spearman's rho correlation coefficient statistics for best management practices, by category.

[Modified from Granato and others (2021). BMP, best management practice; min, minimum; LBMPV, lower bound of the most probable value; UBMPV, upper bound of the most probable value; max, maximum; avg, theoretical trapezoidal average; med, theoretical trapezoidal median; pct GT 1, the theoretical percentage of storms in which outflows exceed inflows and whose ratio is thus greater than 1 (the percentage of outflow ratios greater than one is calculated by using the volume-reduction statistics in this table; the volume-reduction statistics are for the trapezoidal distribution of the ratio of outflow to inflow volume); rho, the Spearman's rho correlation coefficients, calculated by using the ranks of the inflow volumes and the associated ratios of outflow to inflow volumes]

\begin{tabular}{cllcccccccc}
\hline \multicolumn{2}{l}{ International BMP category } & \multicolumn{9}{c}{ Volume-reduction statistics, unitless ratio } \\
\cline { 1 - 7 } Code & \multicolumn{1}{c}{ Name } & Min & LBMPV & UBMPV & Max & Avg & Med & Pct GT 1 & rho \\
\hline BI & Grass strip & 0 & 0.0202 & 0.0317 & 1.2428 & 0.421 & 0.371 & 3.9 & 0.42 \\
BS & Grass swale & 0.0671 & 0.0671 & 0.4966 & 0.8882 & 0.390 & 0.380 & 0.0 & 0.68 \\
GB & Generic BMP & 0.2382 & 0.5199 & 0.7629 & 1.1889 & 0.685 & 0.677 & 7.0 & 0.44 \\
MF & Media filter & 0.4836 & 0.4836 & 0.5033 & 1.3773 & 0.782 & 0.746 & 17.8 & 0.28 \\
\hline
\end{tabular}


each analysis in the model archive for this study (Granato and Friesz, 2021). The CalTrans BMPs simulated in this study use surrogate or category-level values for 12 constituents without sufficient data (table 5), 10 of which were added to statistics calculated by Granato and others (2021).

\section{Results}

In this study, 368 analyses were done to examine highway and urban runoff yields in California (Granato and Friesz, 2021). Precipitation statistics for ecoregion 1, a humid area, and ecoregion 5, an arid area (table 2), were used in 111 analyses in each ecoregion to identify a robust master seed ID for the remaining highway and urban runoff simulations. Analyses were done for 12 ecoregions with highway runoff quality statistics for sites that are 100 and 60 percent impervious. Highway runoff quality analyses also were done for sites that are 100 and 60 percent impervious in 31 TMDL areas. Analyses were done for 12 ecoregions with urban runoff quality statistics for sites that are 100 percent impervious by using the SELDM highway and nonhighway runoff coefficient statistics. Most of the analyses in this study were done by using the generic BMP. Alternative analyses for the BI, BS, and MF BMPs also were done for 12 ecoregions with highway runoff quality statistics for sites that are 100 percent impervious. The results of all these analyses are documented in the model archive associated with this study (Granato and Friesz, 2021). Only examples selected to illustrate stochastic-analysis concepts are discussed in this report.

The random-seed analysis was done to identify a master seed value that would provide the most representative results for the simulated highway runoff volumes. The site of interest for these analyses was simulated as completely impervious. The 111 test simulations for ecoregion 1, the Coast Range, resulted in a range of 1,812 to 1,891 events representing 26 to 27 annual load accounting years. The average annual precipitation values ranged from 58.1 to 62 inches per year, the average annual runoff ranged from 45.6 to 49.3 watershed inches (the flow volumes divided by the drainage area) per year, and the average annual BMP discharge ranged from 34.3 to 37.4 watershed inches per year among simulations. The 111 test simulations for ecoregion 5, the Sierra Nevada, that used the same master-seed values as the associated ecoregion 1 simulations, resulted in a range of 1,234 to 1,270 events representing 38 to 40 annual load accounting years. The average annual precipitation values ranged from 31.9 to 34.8 inches per year, the average annual runoff ranged from 25.1 to 27.4 watershed inches per year, and the average annual BMP discharge ranged from 18.8 to 20.9 watershed inches per year among simulations. The master random-seed ID value 931 was chosen for the interpretive analyses because simulation results based on this seed in both ecoregions were closest to the median of the combined rank of the long-term average highway runoff volumes. This seed ID value resulted in 1,877 events and 27 annual load accounting years in ecoregion 1, and 1,245 events and 38 annual load accounting years in ecoregion 5. The long-term average annual precipitation was 60.4 inches per year, the runoff was 47.1 watershed inches per year, and the BMP discharge was 35.6 watershed inches per year in ecoregion 1 . The long-term average annual precipitation was 33.6 inches per year, the runoff was 26.1 watershed inches per year, and the BMP discharge was 19.8 watershed inches per year in ecoregion 5 .

Although ecoregions 1 and 5 were used in the randomseed analysis, simulation results from ecoregion 6 will be used to illustrate the results of analysis. Results from the ecoregion 6 simulations were selected for discussion because this ecoregion contains the largest number of TMDL areas simulated in this project (table 4). The large number of TMDL areas is probably a result of the many urban areas in ecoregion 6 , including the four largest metropolitan areas in California (Los Angeles, San Diego, San Jose, and San Francisco). Also, precipitation statistics for ecoregion 6 are close to the medians for all the ecoregions with areas in California (table 3) and are well within the ranges of precipitation statistics used for the level-2 simulations of this ecoregion (fig. 2). Although discussions in this report are limited to selected examples, results from all 368 simulations are available in the model archive assembled by Granato and Friesz (2021).

\section{Hydrologic Analysis}

In the ecoregion 6 analyses that used 931 as the master random-seed ID, SELDM generated 1,068 runoff events representing 50 annual load accounting years. Figure 4 shows the population of simulated events, including the precipitation in inches, and the runoff and BMP discharge values in watershed inches. In these simulations, precipitation ranges from about 0.10 to 4.35 inches with a median of 0.596 and an average of 0.797 inches. In the highway runoff coefficient scenario with a total impervious area (TIA) value of 1.0 (HRC100), highway runoff ranged from 0.0137 to 3.33 inches with a median of 0.438 and an average of 0.619 inches. In the urban runoff coefficient scenario with a TIA value of 1.0 (URC100), urban runoff ranged from 0.0574 to 3.37 inches with a median of 0.435 and an average of 0.609 inches. In the highway runoff coefficient scenario with a TIA value of 0.6 (HRC060), highway runoff ranged from 0.0003 to 2.485 inches with a median of 0.249 and an average of 0.364 inches. The differences in runoff coefficient statistics between the highway and urban runoff equations result in the differences in runoff volume populations. Figure 4 emphasizes differences at the low end, but differences between the highway and urban runoff flows with TIA values of 1 are pronounced only above the 98th percentile event. The differences between the runoff volumes for the highway runoff equations with TIA values of 1 and 0.6 are not linear with respect to the difference in TIA. Based on the average of event flows, reducing the imperviousness by 40 percent results in a reduction of runoff flows of about 59 percent in these simulated events. 


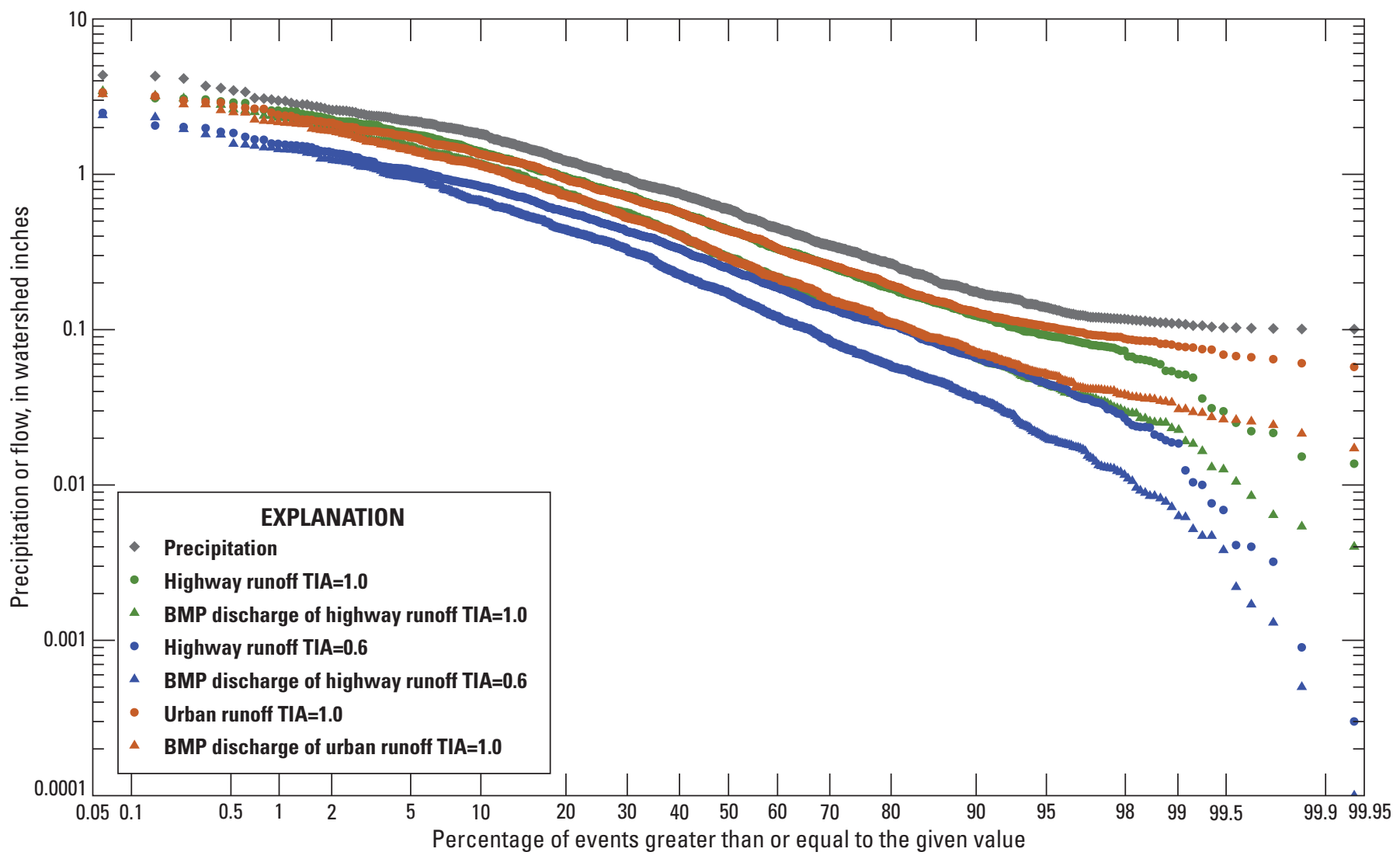

Figure 4. Scatter plot showing the populations of precipitation, runoff, and structural best management practice (BMP) discharge by event in ecoregion 6 simulated by using the Stochastic Empirical Loading and Dilution Model. Runoff from the simulated site is shown with a total impervious area (TIA) fraction equal to 0.6 and 1.0 with the use of the highway runoff coefficient equations (HRC100 and HRC060), and a TIA fraction of 1.0 with the use of the urban and highway runoff coefficient equations (URC100). A watershed inch is the flow volume divided by the drainage area.

The long-term average-annual precipitation and runoff values are calculated by dividing the sum of all individual values by the length of the simulation period. The individual annual values indicate the potential short-term variability in annual loads that may be used to assess a TMDL margin of safety (fig. 5); however, because the annual load accounting years are random collections of events, the long-term average-annual value is the most robust estimate for a TMDL allocation (Novotny, 2004; Granato, 2013; Granato and Jones, 2017). The long-term averages of the annual runoff coefficients are $0.778,0.459$, and 0.764 for the HRC100, HRC060, and URC100, respectively. In these simulations, the runoff coefficients are slightly less than their theoretical values (Granato, 2013) primarily because the most extreme events were not paired with a runoff coefficient value of 1 . In theory, such large events would be correlated with the runoff coefficient, but for most events that are of concern for waterquality regulation, runoff coefficients (the ratios of runoff to rainfall) are not strongly correlated to precipitation (Athayde and others, 1983; Driscoll and others, 1990; Granato, 2010a).
This correlation value is low partly because of environmental variability and partly because the precipitation volume is the denominator of the runoff coefficient (Granato, 2010a, 2013).

\section{Runoff Quality Analysis}

Four water-quality constituents were selected as examples for discussion in this report because they are constituents of concern in California (California State Water Resources Control Board, 2017) and because data were available from multiple sites for these constituents (table 5). Total suspended solids (TSS, p00530) was selected because sediment is a concern in 27 of 83 TMDL areas, and data are available from 71 CalTrans and 241 urban runoff monitoring sites. Total nitrogen (TN, p00600) and total phosphorus (TP, p00665) were selected because nutrients are a concern in 14 TMDL areas, and data are available from multiple sites in the CalTrans and urban runoff monitoring datasets. TN and TP commonly are the nutrients limiting eutrophication in coastal and inland waters, respectively. Total zinc (TZn, p01092) was selected because minor and trace elements are a concern 


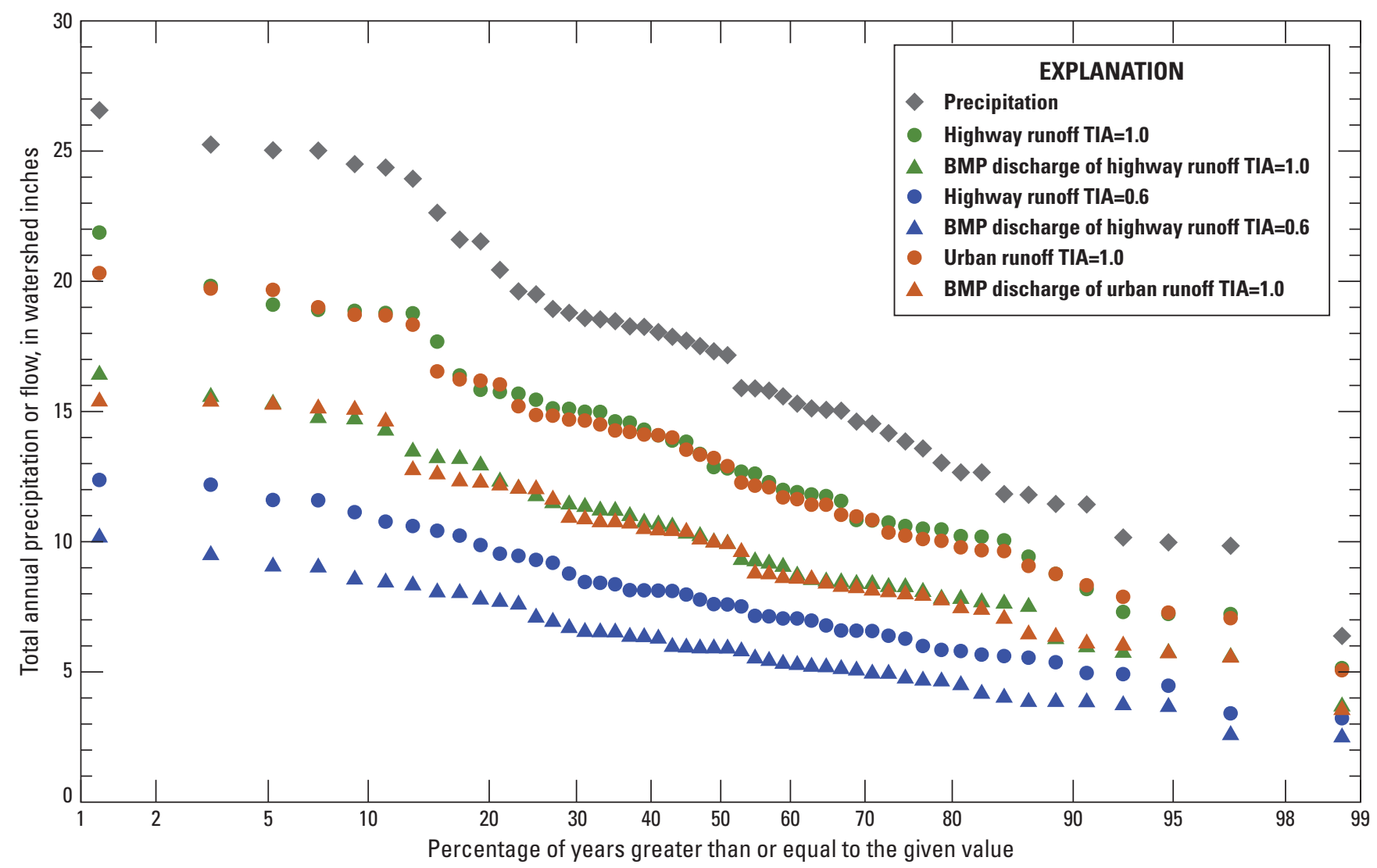

Figure 5. Scatter plot showing the populations of precipitation, runoff, and structural best management practice (BMP) discharge by annual load accounting year in ecoregion 6 simulated by using the Stochastic Empirical Loading and Dilution Model. Runoff from the simulated site is shown with a total impervious area (TIA) fraction equal to 0.6 and 1.0 by using the highway runoff coefficient equations (HRC100 and HRC060), and a TIA fraction of 1.0 by using the urban runoff coefficient equations (URC100).

in 16 TMDL areas, and data are available from 70 CalTrans and 169 urban runoff monitoring sites. The total (unfiltered) constituents were selected over the associated dissolved (filtered) constituents because the sample-filtration process adds variability and uncertainties to measured concentrations (Granato and others, 2003). Also, reductions of filtered constituents measured in BMP outflows may reflect partitioning to suspended solids in the outflow rather than actual load reductions by retention within the BMP (Granato and others, 2021). All 53 water-quality properties and constituents listed in table 5 were simulated in the highway and urban runoff analyses documented by Granato and Friesz (2021), but these four constituents are sufficient for demonstrating approaches for assessing long-term annual yields of highway and urban runoff in California.

SELDM was used to generate EMCs for 1,068 runoff events representing 50 annual load accounting years in the ecoregion 6 analyses. In EMC simulations for TSS, TN, TP, and TZn in highway and urban runoff and BMP discharge (fig. 6), the concentrations for each constituent vary by about 1.7 to 2.8 orders of magnitude. The highway runoff concentrations were simulated by using the statistics in table 6 , and the urban runoff concentrations were simulated by using the statistics in table 7. The CalTrans pavement runoff concentrations simulated with statistics from the HRDB (Granato and Friesz, 2021) are higher than the national urban-runoff values simulated with statistics from the BMPSE (Granato, 2021a), which represent the median of many sites with different land uses and impervious fractions. Comparison of the averages in tables 6 and 7 indicates that, on average, the geometric mean highway runoff concentrations are about 1.35 times the associated urban runoff values. Measured AADT at highway runoff monitoring stations are biased high in comparison to the AADT measured throughout the State (fig. 3), and the AADT at highway sites is strongly correlated to imperviousness near the highway (with a Spearman's rho of 0.78 between the AADT and the TIA within a 0.5 -mile radius around the monitoring station and a rho of 0.76 between the AADT and the TIA within a 1-mile radius around the monitoring station). Therefore, the simulation results and comparison of input statistics indicate that simulating roadway yields with the median of highway site statistics (table 6) provides robust yield estimates. 


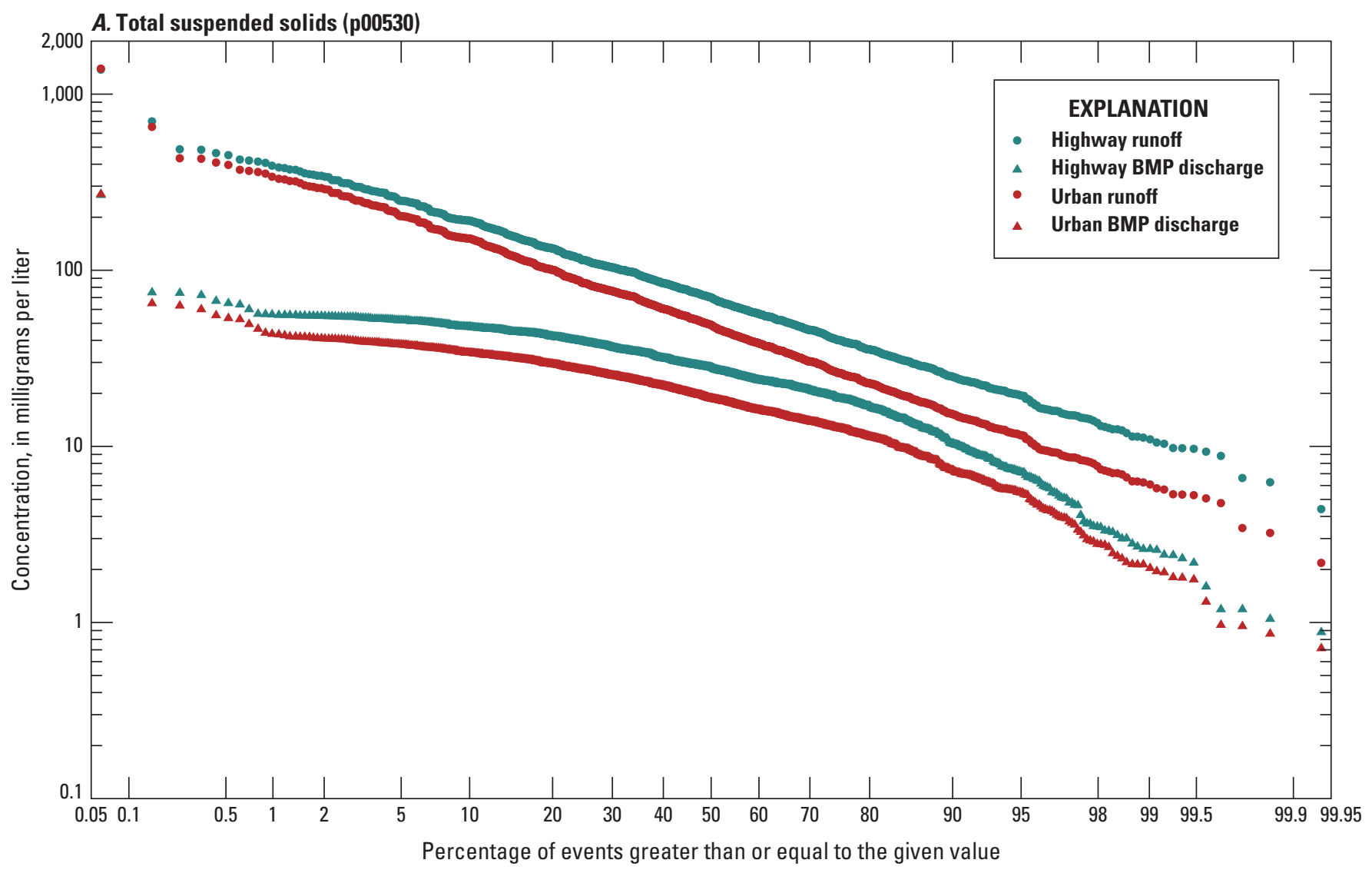

Figure 6. Scatter plot showing the populations of $A$, Total suspended solids (p00530); $B$, Total nitrogen (p00600); $C$, Total phosphorus (p00665); and D, Total zinc (p01092) concentrations in highway and urban runoff and in structural best management practice (BMP) discharge by event, that were simulated by using the Stochastic Empirical Loading and Dilution Model. 

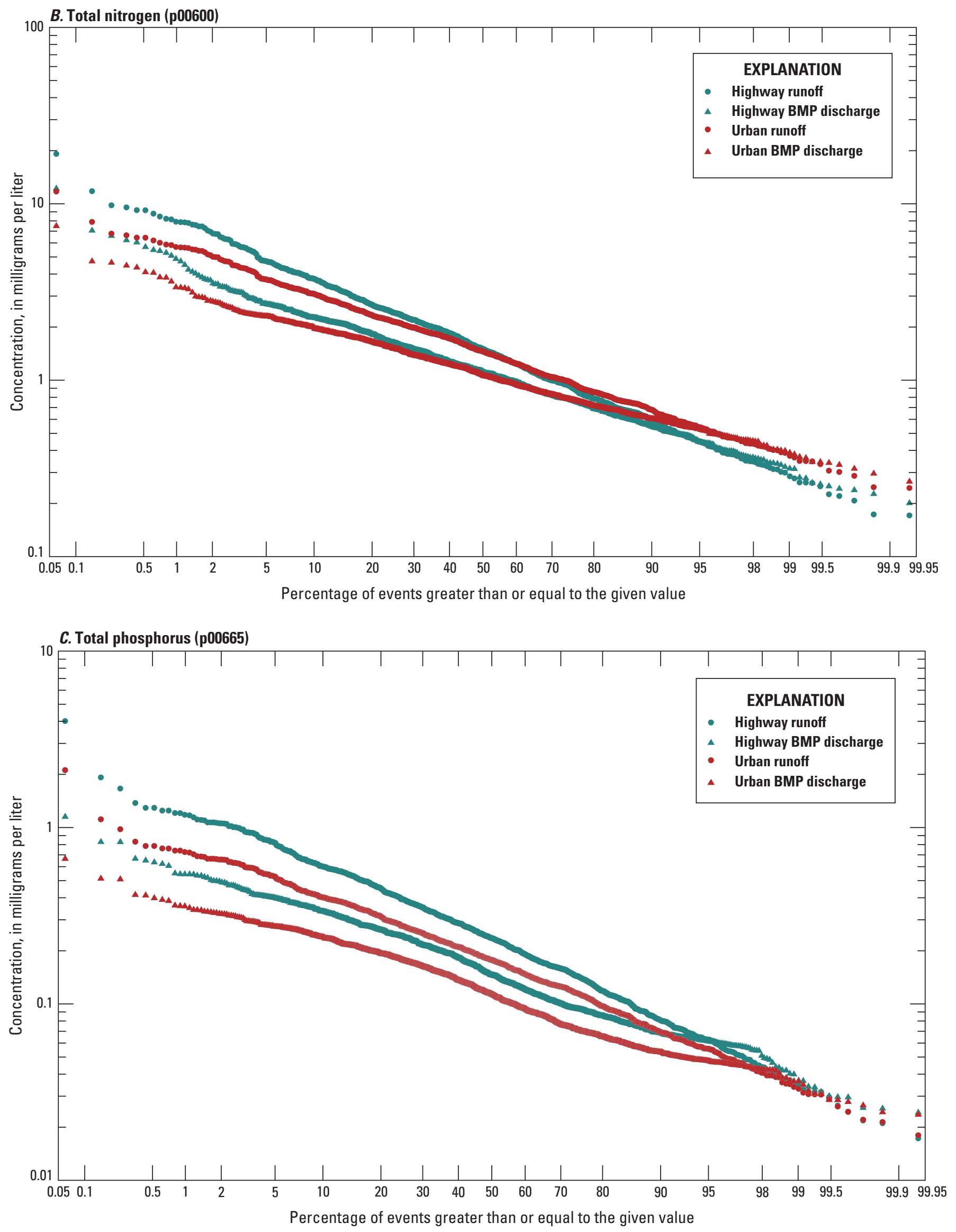

Figure 6.-Continued 


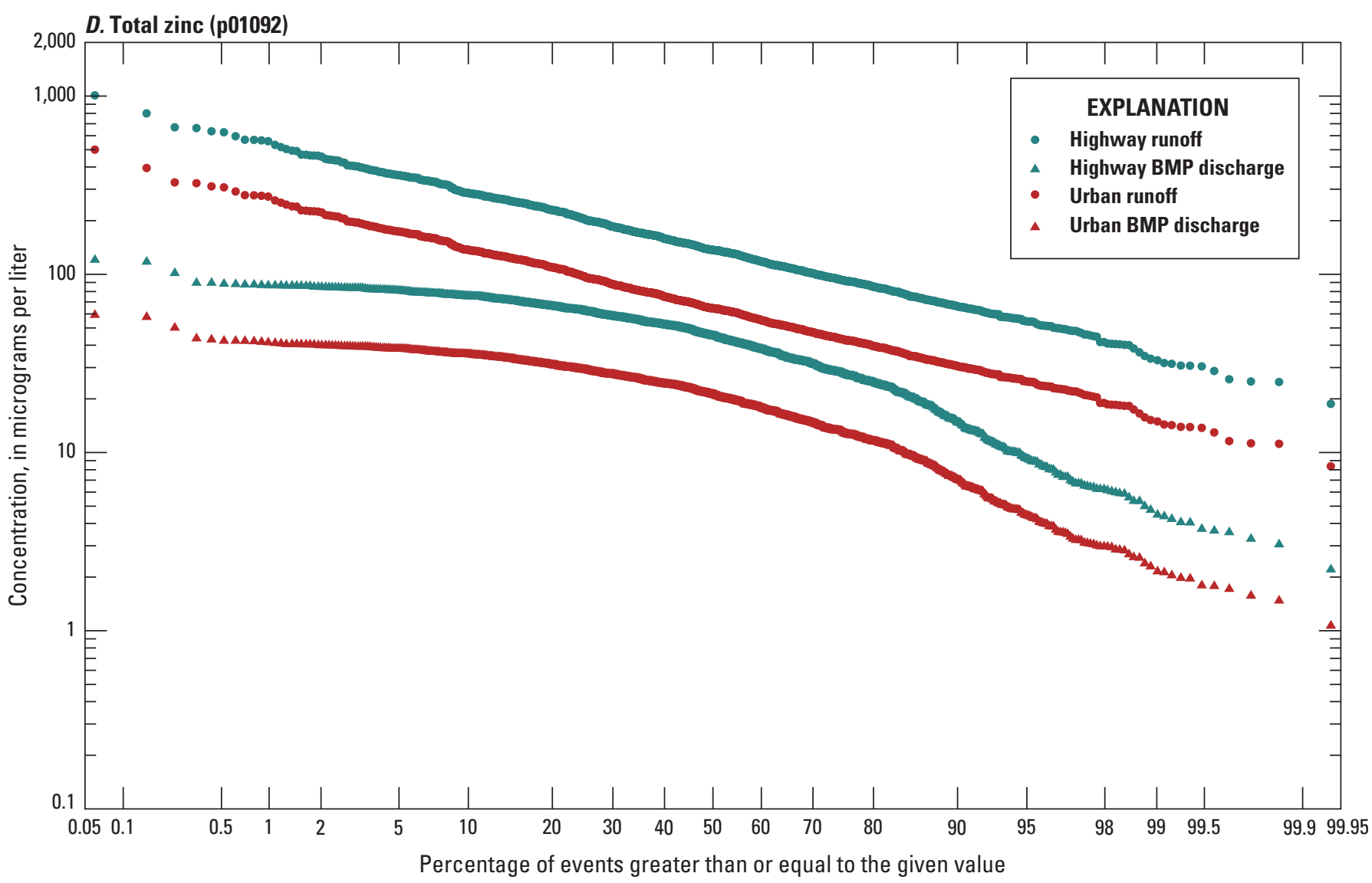

Figure 6.-Continued

The EMC from each event is multiplied by the flow from each event to calculate event loads, and the individual loads are summed for each annual load accounting year to calculate the long-term population of annual load values for each constituent. Because the site of interest was simulated with an area of 1 acre, these loads also are yields in pounds per acre per year. Figure 7 shows the population of simulated annual yields for the four selected constituents. In these simulations, annual highway runoff yields vary by a factor of 4 to 5 , and urban runoff yields vary by a factor of 5 to 6 during the 50 -year simulation period. The long-term average TSS yield from the 100 percent impervious highway site (HRC100) was about 278 pounds per acre per year, and the yield from the 60 percent impervious highway site (HRC060) was about 165 pounds per acre per year (table 9 ). This difference in yields represents the reduction in runoff flow per unit area but not changes in runoff quality that may be caused by routing runoff across the highway median and shoulders because the same concentration statistics were used for both scenarios. Similarly, the ratio of long-term average HRC060 to HRC100 yields was about 0.59 , which is equivalent to the ratio of the average runoff coefficients. The ratio of long-term average highway (HRC100) to urban yields range from 1.13 for TN to 2.10 for TZn for the highway runoff coefficient with urban runoff concentration scenario (HRCU100) and 1.15 for TN to 2.13 for TZn in the urban runoff coefficient with urban runoff concentration scenario (URC100).

\section{Runoff Treatment Analysis}

Simulation of basin-wide BMP performance by using the generic (median) BMP indicates potential flow and yield reductions that may be achieved in a TMDL area with a variety of BMP types operating at various stages in the lifecycle of structural BMPs (Taylor and others, 2014; Granato and others, 2021). Although this report demonstrates use of the long-term average BMP performance results for runoff yield analyses, SELDM randomly generates volume reduction and waterquality treatment values for each event. The theoretical average of the trapezoidal distribution used for volume reduction by the generic BMP is 0.685 , which would result in a reduction of about 31.5 percent. The simulated long-term volume reduction average, which can be calculated by comparing the runoff and discharge flows in table 9 , is about 23.4 percent because the outflow-to-inflow ratios are positively correlated with inflow volume. The theoretical averages of the trapezoidal distribution used for water-quality treatment by the generic BMP are about $0.53,0.83,0.82$, and 0.39 for TSS, TN, TP, and $\mathrm{TZn}$, respectively. The ratios of average BMP to highway 


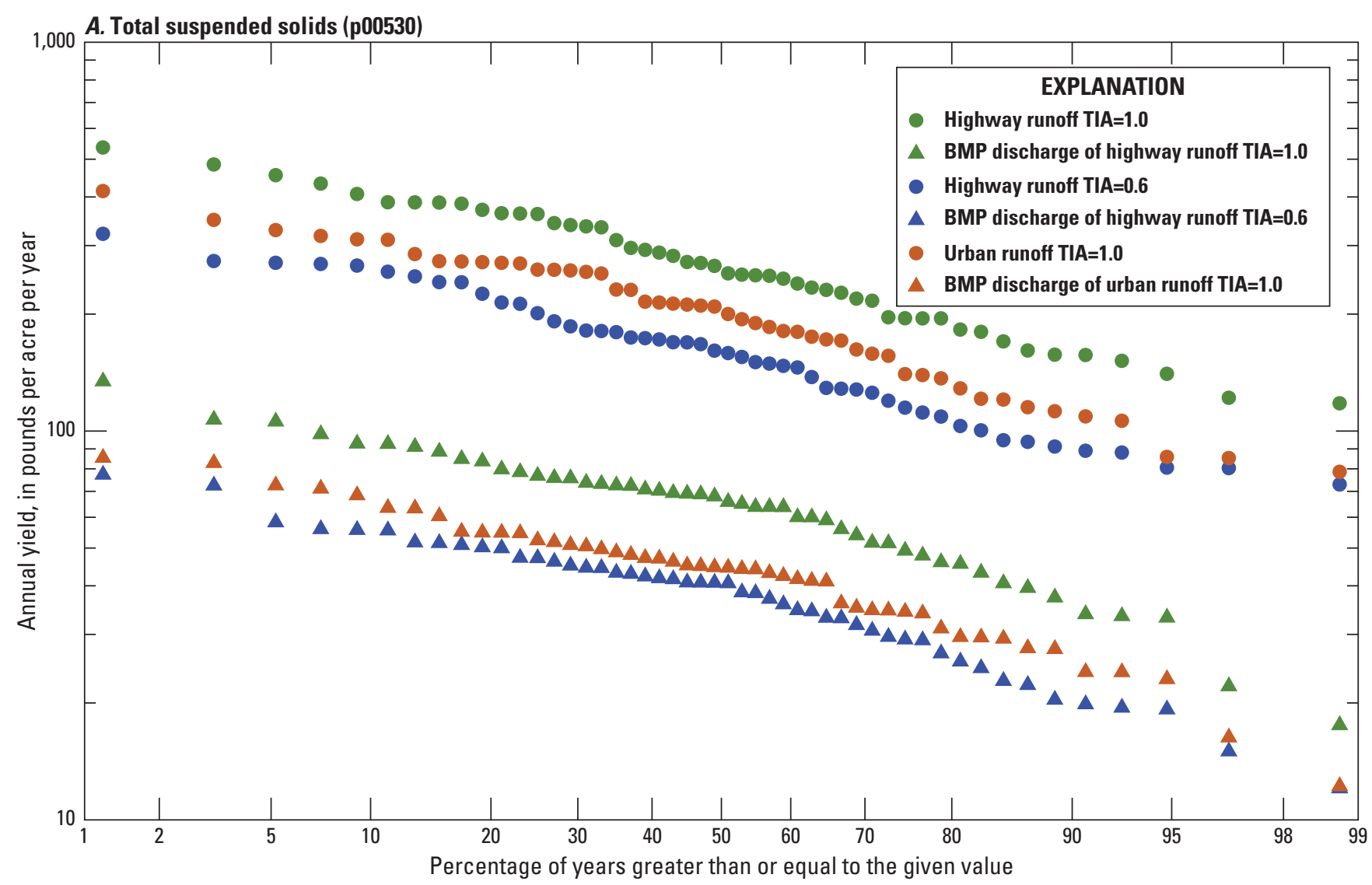

Figure 7. Scatter plot showing the populations of $A$, Total suspended solids (p00530); $B$, Total nitrogen (p00600); $C$, Total phosphorus (p00665); and D, Total zinc (p01092) yields in highway and urban runoff and in structural best management practice (BMP) discharge by annual load accounting year, that were simulated by using the Stochastic Empirical Loading and Dilution Model. 
B. Total nitrogen (p00600)
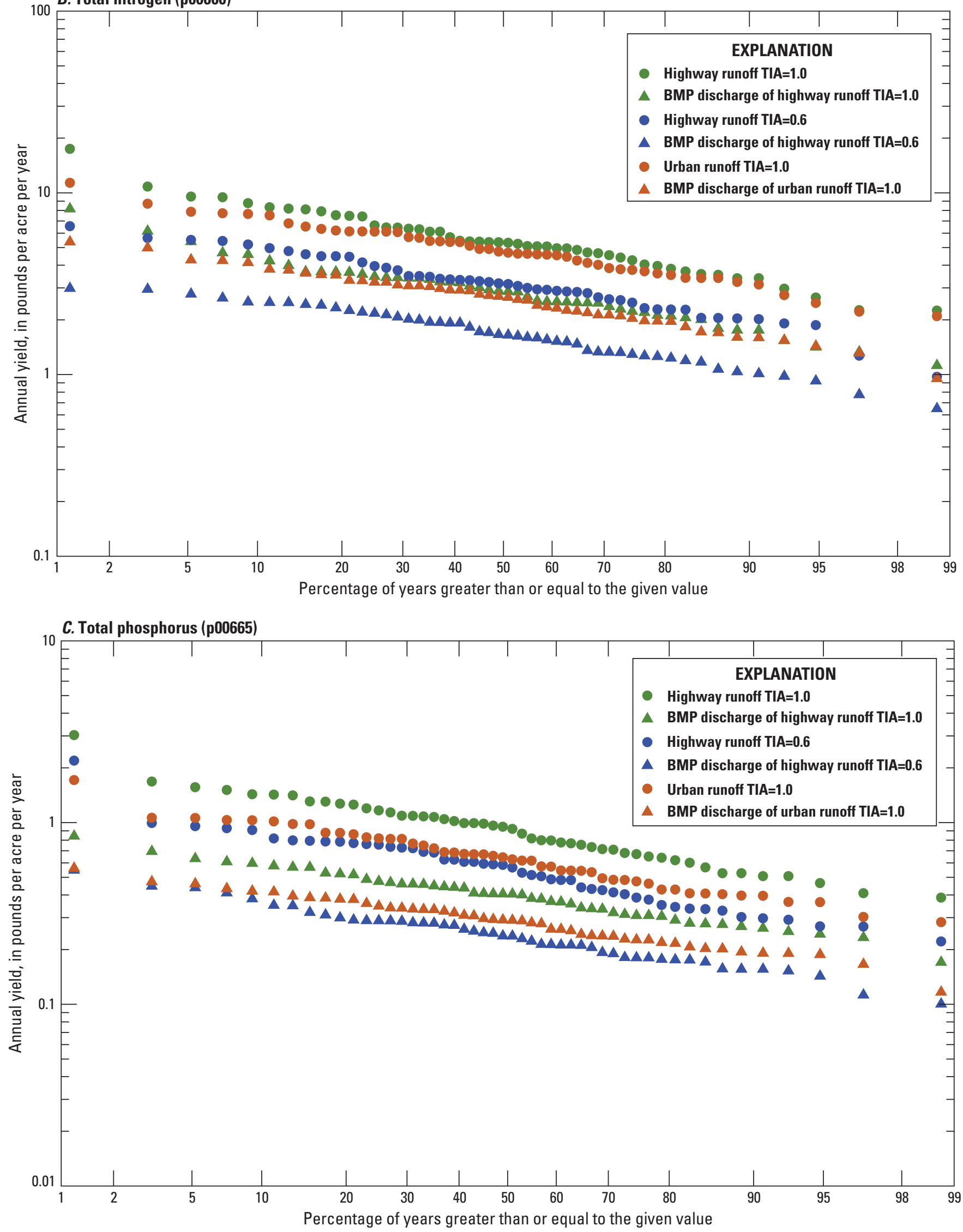

Figure 7.-Continued 


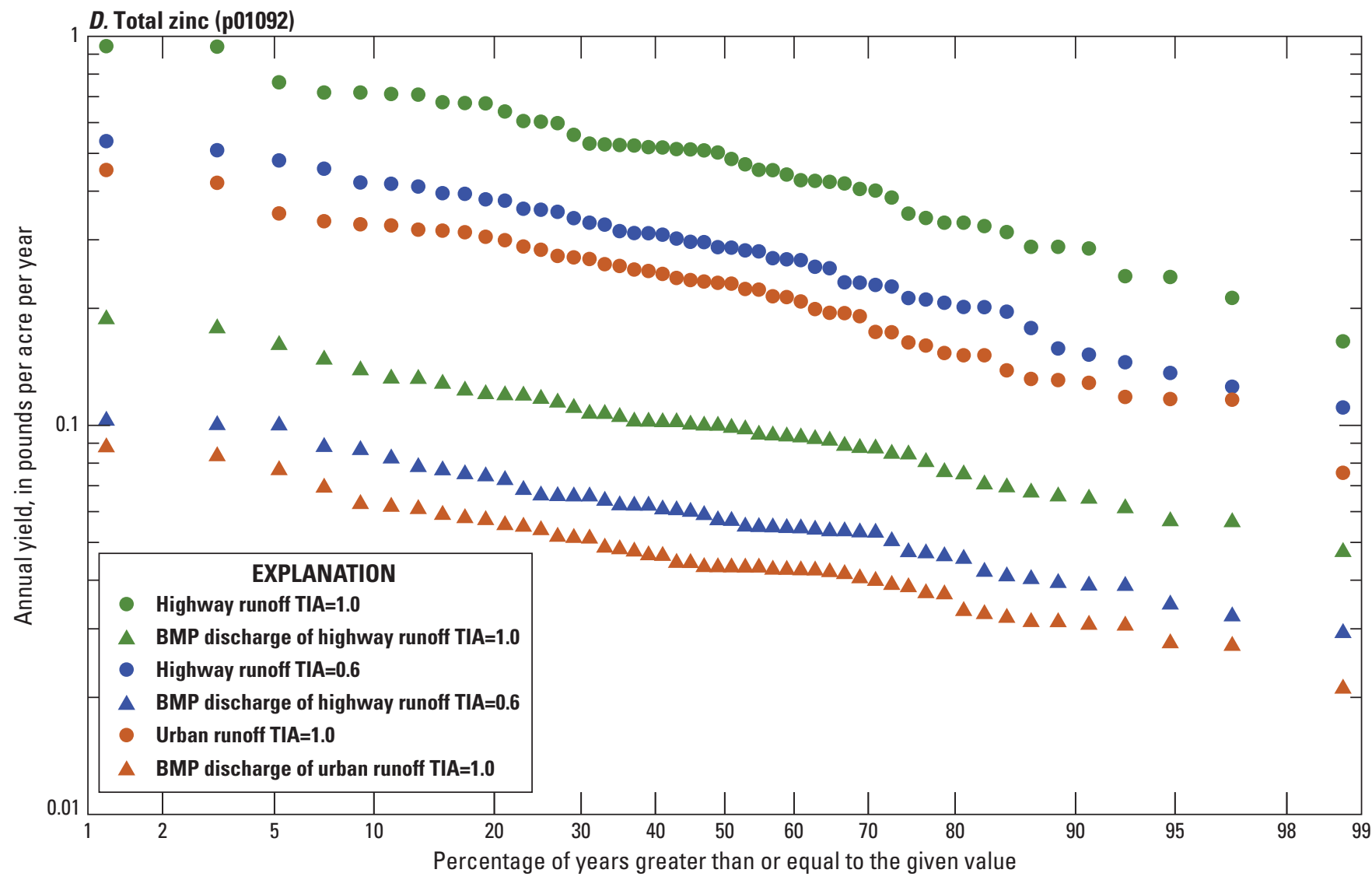

Figure 7.-Continued

Table 9. Long-term average annual yields of selected constituents in highway or urban runoff and structural stormwater best management practice discharge in ecoregion 6, that were simulated by using the Stochastic Empirical Loading and Dilution Model.

[WI, watershed inch (the runoff volume or discharge divided by the drainage area): (lb/ac)/yr, pound per acre per year; p00530, solids, suspended, water, milligrams per liter; p00600, total nitrogen, water, unfiltered, milligrams per liter; p00625, phosphorus, water, unfiltered, milligrams per liter; p01092, zinc, water, filtered, micrograms per liter; BMP, best management practice; TIA, total impervious area as a fraction of the total area]

\begin{tabular}{|c|c|c|c|c|c|}
\hline \multirow{2}{*}{ Scenario } & \multirow{2}{*}{ Flow (WI) } & \multicolumn{4}{|c|}{ Water-quality constituent yields ([lb/ac]/yr) } \\
\hline & & p00530 & p00600 & p00665 & p01092 \\
\hline \multicolumn{6}{|c|}{ Highway runoff coefficient scenario with a TIA value of 1.0 and highway runoff concentrations } \\
\hline Biofiltration (grass) strip & 6.95 & 37.1 & 2.54 & 0.313 & 0.072 \\
\hline Biofiltration (grass) swale & 6.62 & 47.0 & 2.69 & 0.506 & 0.084 \\
\hline Media filter & 11 & 41.3 & 3.3 & 0.1 & 0.088 \\
\hline \multicolumn{6}{|c|}{ Highway runoff coefficient scenario with a TIA value of 0.6 and highway runoff concentrations } \\
\hline Runoff & 7.77 & 165 & 3.31 & 0.596 & 0.292 \\
\hline Generic BMP & 5.99 & 38.8 & 1.74 & 0.25 & 0.06 \\
\hline \multicolumn{6}{|c|}{ Highway runoff coefficient scenario with a TIA value of 1.0 and urban runoff concentrations } \\
\hline Runoff & 13 & 206 & 5.05 & 0.669 & 0.231 \\
\hline Generic BMP & 9.9 & 44.8 & 2.72 & 0.297 & 0.046 \\
\hline
\end{tabular}


concentrations are about $0.31,0.68,0.59$, and 0.28 for TSS, $\mathrm{TN}, \mathrm{TP}$, and TZn, respectively. Theses averages are lower than the nominal average trapezoidal ratios because of the negative correlation between inflow concentration and the concentration ratios (Granato, 2014; Granato and others, 2021).

The long-term average load reduction ratios, which included concentration and volume reductions for these constituents, are much lower than the concentration ratios at about $0.23,0.53,0.43$, and 0.20 for TSS, TN, TP, and TZn, respectively. These long-term average load reduction ratios are equivalent to mass reductions of about $77,47,57$, and 80 percent for TSS, TN, TP, and TZn, respectively. Such values may represent reductions that are the maximum extent practicable on a watershed scale, especially for existing urban areas with many design and economic constraints (National Research Council, 2009; National Academies of Sciences, Engineering, and Medicine, 2015).

Alternate HRC100 scenarios also were run to examine BMP performance by using the BI, BS, and MF statistics (table 8); the results for ecoregion 6 are listed in table 9. On average, the BS BMP has the highest volume-reduction capacity (about 50 percent) and the MF BMP has the lowest volume-reduction capacity (about 17 percent) of the simulated results (table 9). On average, among the constituents included in table 9, the MF has the highest yield-reduction capacity (about 75 percent), and the generic BMP has the lowest yieldreduction capacity (about 65 percent).

\section{Application of Results}

Application of simulated runoff yields to actual TMDL areas in California is beyond the scope of this report, but information from the USGS StreamStats web-based application (U.S. Geological Survey, 2020) was used to illustrate load calculations by using information from the literature. Actual loads would be calculated by using detailed data on basin properties, development, road geometry, and the highway and urban storm-sewer network with GIS software. To estimate the potential area of urban imperviousness and highways for load calculations without doing a detailed GIS analysis, information about the TIA, percentage of roads, and the percentage of highways is needed. To do an actual or example analysis, stormwater yields (in pounds per acre per year, such as the ones listed in table 9) would be multiplied by measured or estimated land-cover areas to estimate watershed loads.

The USGS StreamStats application (U.S. Geological Survey, 2020) was used to obtain estimates of the drainage area, total developed areas (TDA), and TIA in 41 river and stream basins containing TMDL reaches (table 10). The drainage areas ranged from 7.3 to 10,194 square miles $\left(\mathrm{mi}^{2}\right)$ with a median of about $303 \mathrm{mi}^{2}$. The percent TDAs ranged from 1.8 to 99 with a median of 7.4 percent. The percent TIA ranged from 0.1 to 65.1 with a median of 1.2 percent. The percentage of TDA that is impervious ranged from 1.79 to 66.3 with a median of 13.6 percent. The imperviousness of the developed area has a strong positive correlation to the percentage of developed area $(\mathrm{rho}=0.8)$, which indicates the urban intensification (increasing TIA per unit area) that occurs with increasing development. However, these development and impervious values are basin-wide values that may not represent the TDA and TIA in individual TMDL subbasins within the larger river basins.

The penultimate step in developing hypothetical estimates of long-term annual loads is to estimate the highway and nonhighway portions of the basin-wide TIA. Studies of the components of impervious surfaces in developed areas consistently indicate that, on average, off-street parking, roofs, roads, and other anthropogenic surfaces comprise about 35 , 32,25 , and 8 percent of the TIA in these areas, respectively (Tilley and Slonecker, 1996; Roy and Shuster, 2009; Wang, 2013). Spaetzel and others (2020) did a geographic analysis of road lengths in nested basins above road crossings and found that in 8,679 subbasins with drainage areas greater than 1 square mile that contained a nonzero highway length, the ratio of highways (defined as controlled access highways, ramps, secondary highways, or major connecting roads) to total road lengths ranged from $3 \times 10^{-6}$ to 1 , with an average ratio of 0.13. The American Association of State Highway and Transportation Officials (2001) estimate that arterial roads comprise about 8 percent of roads in rural areas and 20 percent in urban areas nationwide. The Federal Highway Administration (2015) national census of roads indicates that CalTrans owns about 6.7 percent of roadways in the State (table 1). Therefore, if all roads are 25 percent of the impervious area and highways are 6.7 percent of roads, then percentage of highways in the hypothetical basin may be estimated as about 1.7 percent of the TIA and other developed-area imperviousness is 98.3 percent of the TIA.

The final step in developing the hypothetical load estimates is to multiply the yields times the areas. Using the median values from table 10 (a drainage area of 303 square miles and TIA of 1.2 percent) would result in 3.63 square miles of impervious surface. Assuming the highways were 1.7 percent of the TIA would result in an area of about 0.06 square miles (about 38 acres) of highway and 3.57 square miles (about 2,285 acres) of nonhighway impervious surfaces. Multiplying the highway runoff (HRC100) yields for ecoregion 6 (table 9) by the highway area would result in loads of about 19,500; 407; 68; and 34 pounds of TSS, TN, TP, and TZn, respectively from the highway. These loads would be reduced to about 4,590;212;28.9; and 7.07 pounds of TSS, TN, TP, and TZn, respectively if the generic BMP yields are applied. However, Washburn and others (2010) sampled areas in Sacramento, Irvine, and Santa Cruz California and found that on average the imperviousness of highway rights of way were only about 47 percent of the right-of-way, indicating that grassy swales are a ubiquitous feature of CalTrans rights-ofway. If the swale-discharge yields in table 9 are used, then the highway loads would be reduced to about 3,$290 ; 188$; 35.4; and 5.88 pounds of TSS, TN, TP, and TZn, respectively. In comparison, the urban impervious loads based on 
Table 10. Selected StreamStats basin properties for streams and rivers in total maximum daily load areas of California.

[StreamStats data are from U.S. Geological Survey (2020). DRNAREA, area that drains to a point on a stream, in square miles; LC11DEV, percentage of developed (urban) land from the National Land Cover Database (NLCD) 2011 classes 21-24 (U.S. Geological Survey, 2014); LC11IMP, average percentage of impervious area determined from NLCD 2011 impervious dataset (U.S. Geological Survey, 2014); IMPDEV, percentage of developed (urban) land (LC11DEV) that is impervious]

\begin{tabular}{|c|c|c|c|c|c|c|}
\hline \multirow{2}{*}{ Basin name } & \multicolumn{2}{|c|}{ Delineation point } & \multicolumn{3}{|c|}{ StreamStats basin properties } & \multirow{2}{*}{ IMPDEV } \\
\hline & Latitude & Longitude & DRNAREA & LC11DEV & LC11IMP & \\
\hline Albion River & 39.22531 & -123.76783 & 42.6 & 5.10 & 0.2 & 3.92 \\
\hline Ballona Creek & 33.96345 & -118.45259 & 133.1 & 89.5 & 51.9 & 58.0 \\
\hline Big Bear Lake & 34.2428 & -116.97637 & 35.9 & 43.3 & 9.70 & 22.4 \\
\hline Big River & 39.30189 & -123.79212 & 181.6 & 4.40 & 0.10 & 2.27 \\
\hline Cache \& Bear Creeks & 38.72106 & -121.71577 & 678.1 & 3.50 & 0.30 & 8.57 \\
\hline Calleguas Creeks tribs & 34.10926 & -119.09291 & 346.7 & 34.7 & 11.5 & 33.1 \\
\hline Chollas Creek & 32.68773 & -117.12748 & 26.9 & 97.9 & 60.0 & 61.3 \\
\hline Clear Lake & 38.92568 & -122.61457 & 489.2 & 21.4 & 1.20 & 5.61 \\
\hline Dominguez Channel etc & 33.77729 & -118.24119 & 132.4 & 98.2 & 65.1 & 66.3 \\
\hline Garcia River & 38.94593 & -123.72346 & 113.8 & 4.40 & 0.20 & 4.55 \\
\hline Gualala River & 38.76844 & -123.53291 & 298.9 & 2.50 & 0.10 & 4.00 \\
\hline Klamath River & 41.54633 & -124.08062 & $10,193.8$ & 3.60 & 0.30 & 8.33 \\
\hline Lake Elsinore & 33.65732 & -117.33025 & 767.9 & 25 & 6.90 & 27.6 \\
\hline Los Angeles River & 33.7672 & -118.20544 & 831.8 & 61.7 & 31.4 & 50.9 \\
\hline Los Cerritos Channel & 33.76766 & -118.10431 & 41.9 & 99.0 & 62.2 & 62.8 \\
\hline Lower Eel River & 40.62594 & -124.28764 & 302.5 & 7.4 & 1.1 & 14.9 \\
\hline Mad River & 40.94863 & -124.12693 & 496 & 4.00 & 0.40 & 10.0 \\
\hline Malibu Creek & 34.03234 & -118.68002 & 109.6 & 26.4 & 6.50 & 24.6 \\
\hline Middle Fork Eel & 39.71324 & -123.3522 & 753.7 & 3.20 & 0.10 & 3.13 \\
\hline Morro Bay & 35.3434 & -120.83807 & 77.1 & 15.5 & 4.20 & 27.1 \\
\hline Napa River & 38.0781 & -122.24749 & 420 & 19.7 & 6.60 & 33.5 \\
\hline Navarro River & 39.19262 & -123.76045 & 315 & 4.80 & 0.20 & 4.17 \\
\hline Noyo River & 39.43782 & -123.76991 & 109 & 5.60 & 0.10 & 1.79 \\
\hline Rainbow Creek & 33.41108 & -117.21597 & 11.5 & 20.4 & 4.30 & 21.1 \\
\hline Redwood Creek, North Coast & 41.29259 & -124.09135 & 282.5 & 1.80 & 0.10 & 5.56 \\
\hline San Diego Creek & 33.65087 & -117.86727 & 118.6 & 76.0 & 35.8 & 47.1 \\
\hline San Gabriel & 33.75018 & -118.10904 & 675 & 52.1 & 26.2 & 50.3 \\
\hline San Lorenzo River & 36.9909 & -122.03133 & 115.2 & 14.0 & 1.20 & 8.57 \\
\hline San Pedro Creek & 37.59628 & -122.50546 & 7.30 & 28.2 & 8.20 & 29.1 \\
\hline Santa Clara River & 34.23492 & -119.25674 & $1,623.2$ & 9.60 & 2.30 & 24.0 \\
\hline Scott River & 41.77891 & -123.03688 & 814.3 & 3.60 & 0.20 & 5.56 \\
\hline Shasta River & 41.83045 & -122.59367 & 790.7 & 4.10 & 1.10 & 26.8 \\
\hline Sonoma Creek & 38.15778 & -122.40748 & 163.4 & 15.4 & 3.60 & 23.4 \\
\hline South Fork Eel River & 40.35501 & -123.91982 & 689.2 & 4.90 & 0.20 & 4.08 \\
\hline South Fork Trinity & 40.88901 & -123.60173 & 932.1 & 3.70 & 0.10 & 2.70 \\
\hline Ten Mile River & 39.53969 & -123.75103 & 119.6 & 3.70 & 0.10 & 2.70 \\
\hline Trinity River & 41.18515 & -123.70837 & $2,969.8$ & 3.90 & 0.20 & 5.13 \\
\hline Truckee River & 39.464 & -120.00325 & 441.9 & 5.90 & 1.40 & 23.7 \\
\hline Upper Main Eel River & 39.71353 & -123.3534 & 709 & 4.30 & 0.20 & 4.65 \\
\hline Van Duzen & 40.5486 & -124.16074 & 429.4 & 2.30 & 0.10 & 4.35 \\
\hline Ventura River & 34.27456 & -119.30779 & 225.6 & 11.0 & 1.50 & 13.6 \\
\hline
\end{tabular}


the URC100 yields for ecoregion 6 (table 9) would be about 464,$000 ; 11,400 ; 1,510$; and 527 pounds of TSS, TN, TP, and TZn, respectively. The treated urban loads would be about 101,$000 ; 6,130 ; 669$; and 104 pounds of TSS, TN, TP and TZn, respectively. Thus, in this hypothetical example, the treated and untreated highway loads are about 4.7 and 4.3 percent of the corresponding urban loads, respectively, even though the highway yields are higher than the urban yields. Therefore, the highway loads are well within the uncertainty of the measured urban stormwater concentrations (Harmel and others, 2006). Similarly, Stonewall and others (2018) examined long-term average- annual yields and loads from highways and other land covers and found that although highway yields were larger than for other land covers, the highway contributions were a small fraction of the total loads in the Willamette River Basin in Oregon.

These highway and urban loads may be inflated because only a fraction of the total impervious area may drain to receiving waters. The directly connected impervious area (DCIA, the area that actually drains to the receiving water) is expected to be about 0.18 when TIA is about 1.0 percent (Granato, 2010b). If this DCIA value is used to estimate the source area of runoff and BMP discharges in these example calculations, then the long-term average annual loads to receiving waters would be about 18 percent of the example values in the previous paragraph. As TIA increases, however, the DCIA approaches the TIA, so a ratio of 0.18 would not apply in highly developed areas within a largely undeveloped basin (Granato, 2010b).

If detailed GIS data are used to estimate loads for actual TMDL areas, then the analyst must choose which yields to use. In this study, highway yields were simulated by using TIA values of 100 and 60 percent. However, Washburn and others (2010) sampled areas in Sacramento, Irvine, and Santa Cruz California and found that, on average, the imperviousness of highway rights-of-way were only about 47 percent of the total right-of-way areas. In comparison, they found that, on average, the impervious percentages for the local, collector, and arterial roadways were about 87,90 , and 77 percent of the right-of-way areas, respectively. This indicates the potential extent of grass strips and swales outside small stretches of ultra-urban downtown areas. This information supports use of the HRC100 yields for pavement analyses and BMP yields in the HRC100 scenarios (table 9) rather than the HRC60 values to estimate loads from the entire CalTrans rights of way in TMDL areas. The HRC100 BMP statistics may be more representative than the HRC60 values because the HRC60 simulations were done by using pavement-runoff concentration statistics.

\section{Limitations of the Analysis}

The analyses described in this report were designed to produce estimates of stormwater yields from highway and urban land-cover areas with and without BMP treatment for use in multiple TMDL basins across California. SELDM is calibrated by selecting statistics for runoff-quality variables and BMP treatment variables from robust and representative datasets rather than by matching outputs to a historical record (Granato, 2013, 2014; Granato and Jones, 2014, 2017, 2019; Stonewall and others, 2019). Therefore, uncertainties in input values are proportional to uncertainties in the results. There are uncertainties in individual measurements (Harmel and others 2006), population statistics calculated from individual measurements (Haan, 1977; Interagency Advisory Committee on Water Data, 1982; Leutnant and others, 2018), and in the use of statistics from monitored sites to unmonitored sites that affect results from any model (Farmer and Levin, 2018). Although SELDM simulates hydrologic, runoff-quality, and runoff-treatment variables stochastically using literature and public database-derived statistics from hundreds to thousands of sites, application of results to any particular stormwater outfall has considerable uncertainty.

In this study, the average and standard deviation of concentrations from available data were used to simulate more than 1,000 EMCs for each constituent in each analysis. Although the average is the best estimate of the center of the distribution, the value of the average can be substantially biased by either high or low outliers in small datasets (Haan, 1977; Interagency Advisory Committee on Water Data, 1982). Estimates of the average values tend to stabilize more rapidly with each additional sample and are less biased by outliers than the standard deviation or skew because these statistics are calculated by using the sum of squared differences between each value and the average and the sum of cubed differences between each value and the average, respectively. Therefore, uncertainties in these statistics are associated with available sample sizes (Driscoll and others, 1979; Burton and Pitt, 2002; California Department of Transportation, 2009; Granato, 2014; Leutnant and others, 2018). Driscoll and others (1979) recommend the collection of 20-40 EMC samples to characterize runoff for any given site on the basis of the variability of commonly measured runoff constituents. Similarly, Burton and Pitt (2002) indicate that, at a minimum, 25-50 EMC samples may be needed to characterize runoff for any given site. The California Department of Transportation (2009) provides examples in their BMP monitoring handbook that indicate that 50-113 paired EMC samples may be needed just to detect differences in mean concentrations. Leutnant and others (2018) determined that $40 \mathrm{EMC}$ samples would need to be collected to characterize TSS concentrations.

In this study, a minimum threshold of seven events per site was selected to obtain statistics for one or more sites (table 5). Some of the uncertainty in statistics for individual sites and the transfer of statistics from monitored to unmonitored sites is mitigated by use of the median of multiple sites to represent the general characteristics of highway and urban runoff. The median of site statistics represents the central tendency of all site statistics, without the potential influence of extreme outliers that could be caused by monitoring bias or uncharacteristic conditions at a few sites. For example, 
heavy-industrial or mining operations near a highway-runoff monitoring site could substantially bias site statistics and may not be representative of the vast majority of highway miles in the State. Similarly, Granato and others (2021) used the median of BMP performance statistics from multiple sites to develop robust but generalized estimates. The number of sites with sufficient data available for each constituent (table 5) indicates the relative uncertainty of the statistics for highway (table 6) and urban (table 7) runoff constituents used in this report. This comparison, however, is not linear because the constituents with more sites also tend to have more EMCs per site and the uncertainty also depends on the variability in measured values (Haan, 1977; Interagency Advisory Committee on Water Data, 1982).

\section{Summary}

The California Department of Transportation, commonly known as CalTrans, meets responsibilities under Federal and State environmental law as an important part of its mission. In its National Pollution Discharge Elimination System (NPDES) statewide stormwater permit, CalTrans is identified as a stakeholder in 84 areas subject to total maximum daily load (TMDL) regulations. CalTrans maintains thousands of stormwater outfalls and structural stormwater treatment facilities, commonly known as structural stormwater best management practices (BMPs). Although its National Pollution Discharge Elimination System permit is focused on TMDL areas, CalTrans builds and maintains BMPs to minimize adverse effects of roadway runoff on receiving waters throughout the State. Therefore, CalTrans and other MS4 permittees in California and other State departments of transportation nationwide need information about potential yields (loads per unit area) of constituents of concern in stormwater runoff and BMP discharges. The U.S. Geological Survey in cooperation with the Federal Highway Administration developed the Stochastic Empirical Loading and Dilution Model (SELDM) to meet these information needs. SELDM has been selected to provide information about runoff and BMP discharge loads and yields (loads per unit area) from highways and other land covers by the National Cooperative Highway Research Program (Lantin and others, 2019), several other State departments of transportation (Granato and Jones, 2017; Smith and others, 2018; Stonewall and others, 2018, 2019; Weaver and others, 2019), and now CalTrans.

This report describes approaches and statistics used to analyze available hydrologic and runoff-quality data to simulate long-term annual yields of highway and urban runoff constituents of concern with SELDM (version 1.1.0; Granato, 2021b). In this study, 368 analyses were done to examine highway and urban runoff yields in California (Granato and Friesz, 2021). Precipitation statistics for 12 U.S. Environmental Protection Agency (EPA) level III ecoregions that lie in-whole or in-part within the State of
California were simulated to provide statewide planning-level runoff yields. Precipitation statistics for 31 TMDL areas in California also were used to provide more detailed analyses. Highway runoff-quality analyses were done by using SELDM highway runoff equations for sites that are 100 and 60 percent impervious. Urban runoff-quality analyses were done by using SELDM highway and nonhighway runoff equations for sites that are 100 percent impervious. Representative water-quality statistics for 53 water-quality properties and constituents of concern were calculated to simulate runoff event mean concentrations by using CalTrans highway runoff data and national urban runoff data. National BMP statistics for treatment of runoff volumes and concentrations were used to assess the potential for basin-wide reductions. For most of the analyses, the Federal Highway Administration generic BMP statistics were used. Specific BMPs (biofilter strips, biofilter swales, and media filters) commonly used by CalTrans also were simulated on the regional scale.

This report provides the input statistics and methods used for all 368 analyses but results for only 11 selected examples are described to illustrate the approaches used in this study. The hydrology of EPA level III ecoregion 6 (the Southern and Central California Plains and Hills) was used to simulate precipitation and flows. Four water-quality constituents, including total suspended solids, total nitrogen, total phosphorus, and total zinc, were selected as examples because they are widespread constituents of concern with substantial amounts of highway and urban runoff monitoring data. Water-quality treatment statistics for the four BMP categories also were used as selected examples.

In this report, a hypothetical basin was specified by using available geographic information to demonstrate use of the highway and nonhighway yields to estimate long-term annual stormwater loads from developed areas. The examples demonstrating application of these results indicate that highway runoff loads may be a small proportion of the total stormwater loads in a typical basin. This is because State highways commonly are a small proportion of the total impervious area in basins of concern. Also, geographic studies in California indicate that, on average, paved surfaces comprise less than half of the CalTrans rights-of-way, which indicates that local infiltration may substantially reduce the directly-connected portion of highway pavements outside of ultra-urban areas.

Although SELDM simulates hydrologic, runoff-quality, and runoff-treatment variables stochastically using literature and public database-derived statistics from hundreds to thousands of sites, application of results to any particular stormwater outfall has considerable uncertainty. There are uncertainties in individual precipitation, flow, and EMC measurements. Calculated statistics from individual measurements may have considerable uncertainty, especially for water-quality constituents with data from few sites and few samples. Use of statistics from monitored sites to simulate conditions at unmonitored sites also can add uncertainties in results from any method or model. Although CalTrans has one of the most extensive highway-runoff datasets in the country, more sites 
and more samples per site are needed to better characterize variations in highway-runoff quality within and between receiving-water basins. Similarly, although the International BMP database has a substantial amount of data, the available data are not yet sufficient to minimize uncertainty in BMP performance statistics. Results of simulations from this study, however, do provide robust estimates to support basin-scale runoff-load analyses in California. Regional results also may be useful for developing planning-level estimates in areas that are outside California but within the 12 EPA level III ecoregions simulated in this study.

\section{References Cited}

Abdel-Megeed, S.M., 1984, Accuracy of correlation coefficient with limited number of points: Journal of Experimental Education, v. 52, no. 4, p. 188-191. [Also available at https://doi.org/10.1080/00220973.198 4.11011891.]

American Association of State Highway and Transportation Officials, 2001, A policy on geometric design of highways and streets 4th ed.: Washington, D.C., American Association of State Highway and Transportation Officials, 905 p. [Also available at https://sjnavarro.files.wordpress.com/ 2011/08/aashto-2001.pdf.]

Athayde, D.N., Shelley, P.E., Driscoll, E.D., Gaboury, D., and Boyd, G.B., 1983, Results of the nationwide urban runoff program-Volume I, final report: Washington, D.C., U.S. Environmental Protection Agency, 198 p. [Also available at https://www3.epa.gov/npdes/pubs/sw_nurp_vol_1_ finalreport.pdf.]

Barrett, M., Lantin, A., and Austrheim-Smith, S., 2004, Storm water pollutant removal in roadside vegetated buffer strips: Transportation Research Record: Journal of the Transportation Research Board, v. 1890, no. 1, p. 129-140, accessed October 27, 2020, at https://doi.org/ 10.3141/1890-16.

Barrett, M.E., 2005, Performance comparison of structural stormwater best management practices: Water Environment Research, v. 77, no. 1, p. 78-86, accessed October 27, 2020, at https://doi.org/10.2175/106143005X41654.

Brown, S.A., Schall, J.D., Morris, J.L., Doherty, C.L., Stein, S.M., and Warner, J.C., 2009, Urban drainage design manual (3d ed.): Federal Highway Administration Hydraulic Engineering Circular No. 22, FHWA-NHI-10-009, HEC-22, 478 p., accessed October 27, 2020, at https://www.fhw a.dot.gov/engineering/hydraulics/pubs/10009/10009.pdf.

Burton, G.A., Jr., and Pitt, R.E., 2002, Stormwater effects handbook - A toolbox for watershed managers, scientists, and engineers: Boca Raton, Fla., CRC Press, 911 p.
California Department of Transportation, 2009, BMP pilot study guidance manual: California Department of Transportation report CTSW-RT-06-171.02.1, 368 p. [Also available at https://citeseerx.ist.psu.edu/viewdoc/ download?doi=10.1.1.377.9833\&rep=rep1\&type=pdf.]

California Department of Transportation, 2016, Statewide stormwater management plan: California Department of Transportation report CTSW-RT-15-316.051.1, 213 p., accessed May 27, 2021, at https://www.waterboards.ca.gov/ water_issues/programs/stormwater/docs/caltrans/swmp/ swmp_approved.pdf.

California Department of Transportation, 2018a, Total maximum daily load status review report: California Department of Transportation report CTSW-RT-18-379.01.1, 57 p., accessed October 27, 2020, at https://www.waterboar ds.ca.gov/water_issues/programs/stormwater/docs/caltrans/ annual_rpts/fy1718/annual_report_fy2017_2018/tmdl_ status_rpt_2018.pdf.

California Department of Transportation, 2018b, Traffic census program: California Department of Transportation web page, accessed October 27, 2020, at https://dot.ca.gov/ programs/traffic-operations/census.

California Department of Transportation, 2019, Stormwater quality handbook - Project planning and design guide [updated April 2019]: California Department of Transportation report CTSW-RT-17-314.24.1, 305 p., accessed October 27, 2020, at https://dot.ca.gov/programs/ design/manual-project-planning-design-guide.

California Department of Transportation, 2020a, About CalTrans: California Department of Transportation web page, accessed October 27, 2020, at https://dot.ca.gov/aboutcaltrans.

California Department of Transportation, 2020b, Environmental analysis: California Department of Transportation web page, accessed October 27, 2020, at https://dot.ca.gov/programs/environmental-analysis.

California Department of Transportation, 2020c, Maintenance: California Department of Transportation web page, accessed October 27, 2020, at https://dot.ca.gov/programs/ maintenance.

California Department of Transportation, 2020d, Stormwater management program: California Department of Transportation web page, accessed October 27, 2020, at https://dot.ca.gov/programs/environmental-analysis/ stormwater-management-program. 
California State Water Resources Control Board, 2017, National pollutant discharge elimination system (NPDES) statewide storm water permit waste discharge requirements (WDRS) for State of California Department of Transportation: California State Water Resources Control Board Order WQ 2017-0026-EXEC, 304 p., October 27, 2020, at https://www.waterboards.ca.gov/water_issues/ programs/stormwater/docs/caltrans/CalTrans_Permit_ Final_DIT.pdf.

Caruso, J.C., and Cliff, N., 1997, Empirical size, coverage, and power of confidence intervals for Spearman's rho: Educational and Psychological Measurement, v. 57, no. 4, p. 637-654. [Also available at https://doi.org/10.1177/ 0013164497057004009.]

Di Toro, D.M., 1984, Probability model of stream quality due to runoff: Journal of Environmental Engineering, v. 110, no. 3, p. 607-628. [Also available at https://doi.org/10.1061/ (ASCE)0733-9372(1984)110:3(607).]

Driscoll, E.D., Di Toro, D.M., and Thomann, R.V., 1979, A statistical method for assessment of urban stormwater: U.S. Environmental Protection Agency report EPA 440/3-79-023, 436 p. [Also available at https://nepi s.epa.gov/Exe/ZyPDF.cgi/2000KZDZ.PDF?Dockey= 2000KZDZ.PDF.]

Driscoll, E.D., Palhegyi, G.E., Strecker, E.W., and Shelley, P.E., 1989, Analysis of storm event characteristics for selected rainfall gages throughout the United States: U.S. Environmental Protection Agency draft report, 43 p. [Also available at https://nepis.epa.gov/Exe/ZyPURL.cgi? Dockey=P100F7F7.TXT.]

Driscoll, E.D., Shelley, P.E., and Strecker, E.W., 1990, Analytical investigation and research report, v. III of Pollutant loadings and impacts from highway stormwater runoff: Federal Highway Administration, FHWARD-88-008, 160 p. [Also available at https://prd-wret.s3.uswest-2.amazonaws.com/assets/palladium/production/atoms/ files/FHWA-RD-88-008_0.pdf.]

Driscoll, E.D., Shelley, P.E., Gaboury, D.R., and Salhotra, A., 1989, A probabilistic methodology for analyzing water quality effects of urban runoff on rivers and streams: U.S. Environmental Protection Agency EPA 841-R89-101, 128 p. [Also available at https://nepis.epa.gov/Exe/ ZyPURL.cgi?Dockey=20004REH.TXT.]

Farmer, W.H., and Levin, S.B., 2018, Characterizing uncertainty in daily streamflow estimates at ungauged locations for the Massachusetts sustainable yield estimator: Journal of the American Water Resources Association, v. 54, no. 1, p. 198-210, accessed February 2018 at https://doi.org/ $10.1111 / 1752-1688.12603$.
Federal Highway Administration, 2013, Highway functional classification-concepts, criteria, and procedures (2013 edition): Federal Highway Administration, FHWA-PL-13-026, 63 p., accessed February 2, 2021, at https://www.fhw a.dot.gov/planning/processes/statewide/related/highway_ functional_classifications/.

Federal Highway Administration, 2015, Functional system length-2014, [table HM-50 of Highway statistics 2014]: Federal Highway Administration web page, accessed February 2, 2021, at https://www.fhwa.dot.gov/ policyinformation/statistics/2014/hm50.cfm.

Federal Highway Administration, 2020, National bridge inventory (NBI): Federal Highway Administration web site, accessed on October 27, 2020, at https://www.fhwa.dot.gov/ bridge/nbi.cfm.

Gilbreath, A., McKee, L., Shimabuku, I., Lin, D., Werbowski, L.M., Zhu, X., Grbic, J., and Rochman, C., 2019, Multiyear water quality performance and mass accumulation of PCBs, mercury, methylmercury, copper, and microplastics in a bioretention rain garden: Journal of Sustainable Water in the Built Environment, v. 5, no. 4, article 88, 10 p., accessed April 12, 2021, at https://doi.org/10.1061/ JSWBAY.0000883.

Granato, G.E., 2010a, Methods for development of planninglevel estimates of stormflow at unmonitored sites in the conterminous United States: Federal Highway Administration, FHWA-HEP-09-005, $90 \mathrm{p}$.

Granato, G.E., 2010b, Overview of methods used to estimate imperviousness in a drainage basin, app. 6 in Methods for development of planning-level estimates of stormflow at unmonitored sites in the conterminous United States: Federal Highway Administration, FHWA-HEP-09-005, 90 p., 1 CD-ROM.

Granato, G.E., 2013, Stochastic Empirical Loading and Dilution Model (SELDM) version 1.0.0: U.S. Geological Survey Techniques and Methods, book 4, chap. C3, 112 p., accessed June 3, 2020, at https://doi.org/10.3133/tm4C3.

Granato, G.E., 2014, Statistics for stochastic modeling of volume reduction, hydrograph extension, and water-quality treatment by structural stormwater runoff best management practices (BMPs): U.S. Geological Survey Scientific Investigations Report 2014-5037, 37 p., accessed May 27, 2021, at https://doi.org/10.3133/sir20145037.

Granato, G.E., 2019, Highway-runoff database (HRDB) version 1.1.0: U.S. Geological Survey data release, accessed May 27, 2021, at https://doi.org/10.5066/P94VL32J.

Granato, G.E., 2021a, Best management practices statistical estimator (BMPSE) version 1.2.0: U.S. Geological Survey data release, accessed May 27, 2021, at https://doi.org/ 10.5066/P9XBPIOB. 
Granato, G.E., 2021b, Stochastic Empirical Loading and Dilution Model (SELDM) software archive: U.S. Geological Survey software release, accessed May 27, 2021, at https://doi.org/10.5066/P9PYG7T5.

Granato, G.E., and Cazenas, P.A., 2009, Highway-runoff database (HRDB version 1.0) — A data warehouse and preprocessor for the Stochastic Empirical Loading and Dilution Model: Federal Highway Administration, FHWAHEP-09-004, 57 p., accessed June 3, 2020, at https://pubs .usgs.gov/sir/2009/5269/disc_content_100a_web/FHWAHEP-09-004.pdf.

Granato, G.E., and Friesz, P.J., 2021, Model archive for assessing long-term annual yields of highway and urban runoff in selected areas of California with the Stochastic Empirical Loading and Dilution Model (SELDM): U.S. Geological Survey data release, https://doi.org/ 10.5066/P9B02EUZ.

Granato, G.E., and Jones, S.C., 2014, Stochastic Empirical Loading and Dilution Model for analysis of flows, concentrations, and loads of highway runoff constituents: Transportation Research Record: Journal of the Transportation Research Board, v. 2436, no. 1, p. 139-147. [Also available at https://doi.org/10.3141/2436-14.]

Granato, G.E., and Jones, S.C., 2017, Estimating total maximum daily loads with the Stochastic Empirical Loading and Dilution Model: Transportation Research Record: Journal of the Transportation Research Board, v. 2638, no. 1, p. 104-112. [Also available at https://doi.org/10.3141/ 2638-12.]

Granato, G.E., and Jones, S.C., 2019, Simulating runoff quality with the highway-runoff database and the Stochastic Empirical Loading and Dilution Model: Transportation Research Record: Journal of the Transportation Research Board, v. 2673, no. 1, p. 136-142. [Also available at https://doi.org/10.1177/0361198118822821.]

Granato, G.E., Spaetzel, A.B., and Medalie, L., 2021, Statistical methods for simulating structural stormwater runoff best management practices (BMPs) with the Stochastic Empirical Loading and Dilution Model (SELDM): U.S. Geological Survey Scientific Investigations Report 2020-5136, 41 p., accessed February 2, 2021, at https://doi.org/10.3133/sir20205136.

Granato, G.E., Zenone, C., and Cazenas, P.A., eds., 2003, Technical issues for monitoring highway runoff and urban stormwater, v. I of The national highway runoff data and methodology synthesis: Federal Highway Administration, FHWA-EP-03-054, 479 p., accessed February 2, 2021, at https://www.usgs.gov/media/files/fhwa-ep03-054.

Haan, C.T., 1977, Statistical methods in hydrology: Ames, Iowa, Iowa State University Press, 378 p.
Harmel, R.D., Cooper, R.J., Slade, R.M., Haney, R.L., and Arnold, J.G., 2006, Cumulative uncertainty in measured streamflow and water quality data for small watersheds: Transactions of the ASABE, v. 49, no. 3, p. 689-701, accessed March 3, 2021, at https://doi.org/10.13031/ 2013.20488.

Helsel, D.R., and Hirsch, R.M., 2002, Statistical methods in water resources-Hydrologic analysis and interpretation: U.S. Geological Survey Techniques of Water-Resources Investigations, book 4, chap. A3, 510 p. [Also available at https://doi.org/10.3133/twri04A3.]

Hem, J.D., 1992, Study and interpretation of the chemical characteristics of natural water ( $3 \mathrm{~d}$ ed.): U.S. Geological Survey Water-Supply Paper 2254, 263 p. [Also available at https://doi.org/10.3133/wsp2254.]

Interagency Advisory Committee on Water Data, 1982, Guidelines for determining flood flow frequency: U.S. Geological Survey Bulletin 17B, 194 p. [Also available at https://water.usgs.gov/osw/bulletin17b/dl_flow.pdf.]

International Stormwater Best Management Practices Database, 2015, The national stormwater quality database (version 4.02, March 17, 2015): International Stormwater Best Management Practices Database, accessed October 16, 2020, at https://bmpdatabase.org/national-stormwaterquality-database.

Jeznach, L.C., and Granato, G.E., 2020, Comparison of SELDM simulated total-phosphorus concentrations with ecological impervious-area criteria: Journal of Environmental Engineering, v. 146, no. 8, article 04020088, 10 p., accessed February 2, 2021, at https://doi.org/10.1061/ (ASCE)EE.1943-7870.0001763.

Kayhanian, M., Suverkropp, C., Ruby, A., and Tsay, K., 2007, Characterization and prediction of highway runoff constituent event mean concentration: Journal of Environmental Management, v. 85, p. 279-295. [Also available at https://doi.org/10.1016/j.jenvman.2006.09.024.]

Krile, R., Todt, F., and Schroeder, J., 2015, Assessing roadway traffic count duration and frequency impacts on annual average daily traffic estimation-Assessing AADT accuracy issues related to short-term count durations: Federal Highway Administration, FHWA-PL-16-008, 45 p., accessed March 4, 2021, at https://www.fhwa.dot.gov/ policyinformation/travel_monitoring/pubs/aadt/aadt_task 3_final_report_nov_2015.pdf.

Lantin, A., Larsen, L., Vyas, A., Barrett, M., Leisenring, M., Koryto, K., and Pechacek, L., 2019, Approaches for determining and complying with TMDL requirements related to roadway stormwater runoff: National Cooperative Highway Research Program Research Report 918, 144 p., accessed February 2, 2021, at https://doi.org/10.17226/25473. 
Legates, D.R., and McCabe, G.J., Jr., 1999, Evaluating the use of "goodness-of-fit" measures in hydrologic and hydroclimatic model validation: Water Resources Research, v. 35, no. 1, p. 233-241. [Also available at https://doi.org/10.1029/ 1998WR900018.]

Leisenring, M., Hobson, P., Clary, J., and Krall, J., 2013, International stormwater best management practices (BMP) database advanced analysis - Influence of design parameters on achievable effluent concentrations: International Stormwater Best Management Practices Database, 74 p., accessed June 3, 2020, at https://www.bmpdatabase.org/ Docs/BMPDB_AdvancedAnalysis_Final_2013.pdf. [At time of publication, report has been moved and is available at https://static1.squarespace.com/static/5f8dbde10268ab2 24c895ad7/t/5fbd3bfc313e84192f19812f/1606237209852/ 2013_BMPDB_AdvancedAnalysis_Final.pdf.]

Leisenring, M., Hobson, P., Pankani, D., Nguyen, L., Clary, J., Rogers, H., Jones, J., and Strecker, E., 2020, Use of the state department of transportation portal to the international stormwater BMP database: National Cooperative Highway Research Program Project 25-25, Task 120, 111 p., accessed November 11, 2020, at http:/onlinepubs.trb.org/onlinepubs/ nchrp/docs/NCHRP25-25-120Report.pdf.

Leutnant, D., Muschalla, D., and Uhl, M., 2018, Statistical distribution of TSS event loads from small urban environments: Water, v. 10, no. 6, article 769, 11 p., accessed February 21, 2021, at https://doi.org/10.3390/w10060769.

Masoner, J.R., Kolpin, D.W., Cozzarelli, I.M., Barber, L.B., Burden, D.S., Foreman, W.T., Forshay, K.J., Furlong, E.T., Groves, J.F., Hladik, M.L., Hopton, M.E., Jaeschke, J.B., Keefe, S.H., Krabbenhoft, D.P., Lowrance, R., Romanok, K.M., Rus, D.L., Selbig, W.R., Williams, B.H., and Bradley, P.M., 2019, Urban stormwater-An overlooked pathway of extensive mixed contaminants to surface and groundwaters in the United States: Environmental Science \& Technology, v. 53, no. 17, p. 10070-10081, accessed April 12, 2021, at https://doi.org/10.1021/acs.est.9b02867.

National Academies of Sciences, Engineering, and Medicine, 2015, Volume reduction of highway runoff in urban areasGuidance manual: National Cooperative Highway Research Program Report 802, 208 p., accessed December 15, 2020, at https://doi.org/10.17226/22170.

National Research Council, 2009, Urban stormwater management in the United States: Washington, D.C., The National Academies Press, 610 p. [Also available at https://doi.org/ $10.17226 / 12465$.

Novotny, V., 2004, Simplified databased total maximum daily loads, or the world is log-normal: Journal of Environmental Engineering, v. 130, no. 6, p. 674-683. [Also available at https://doi.org/10.1061/(ASCE)07339372(2004)130:6(674).]
Omernik, J., Griffith, G., and Comeleo, R., 2003, Level III ecoregions of the continental United States: U.S. Environmental Protection Agency, 1 pl., scale 1:7,500,000, accessed October 28, 2020, at https://www.epa.gov/ecoresearch/ecoregions.

Risley, J.C., and Granato, G.E., 2014, Assessing potential effects of highway runoff on receiving-water quality at selected sites in Oregon with the Stochastic Empirical Loading and Dilution Model (SELDM): U.S. Geological Survey Scientific Investigations Report 2014-5099, 74 p., accessed June 23, 2020, at https://doi.org/10.3133/ $\operatorname{sir} 20145099$.

Roy, A.H., and Shuster, W.D., 2009, Assessing impervious surface connectivity and applications for watershed management: Journal of the American Water Resources Association, v. 45, no. 1, p. 198-209. [Also available at https://doi.org/10.1111/j.1752-1688.2008.00271.x.]

Santa Clara Valley Urban Runoff Pollution Prevention Program, 2020, Pollutants of concern monitoring reportWater years 2014-2019, pt. D of Watershed monitoring and assessment program integrated monitoring report: Santa Clara Valley Urban Runoff Pollution Prevention Program, 349 p., accessed November 2020 at https://scvurppp.org/ 2020/03/31/integrated-monitoring-report-2/.

Smith, K.P., and Granato, G.E., 2010, Quality of stormwater runoff discharged from Massachusetts highways, 2005-07: U.S. Geological Survey Scientific Investigations Report 2009-5269, 198 p., accessed May 16, 2020, at https://doi.org/10.3133/sir20095269.

Smith, K.P., Sorenson, J.R., and Granato, G.E., 2018, Characterization of stormwater runoff from bridge decks in eastern Massachusetts, 2014-16: U.S. Geological Survey Scientific Investigations Report 2018-5033, 73 p., accessed June 23, 2020, at https://doi.org/10.3133/sir20185033.

Spaetzel, A.B., Steeves, P.A., and Granato, G.E., 2020, Basin characteristics and point locations of road crossings in Connecticut, Massachusetts, and Rhode Island for highwayrunoff mitigation analyses using the Stochastic Empirical Loading and Dilution Model: U.S. Geological Survey data release, accessed September 30, 2020, at https://doi.org/ 10.5066/P9VK1MCG.

Stonewall, A.J., Granato, G.E., and Glover-Cutter, K.M., 2019, Assessing potential effects of highway and urban runoff on receiving streams in total maximum daily load watersheds in Oregon using the Stochastic Empirical Loading and Dilution Model: U.S. Geological Survey Scientific Investigations Report 2019-5053, 116 p., accessed June 23, 2020, at https://doi.org/10.3133/sir20195053. 
Stonewall, A.J., Granato, G.E., and Haluska, T.L., 2018, Assessing roadway contributions to stormwater flows, concentrations, and loads by using the StreamStats application: Transportation Research Record: Journal of the Transportation Research Board, v. 2672, no. 39, 9 p., accessed April 23, 2020, at https://doi.org/10.1177/ 0361198118758679.

Taylor, S., Barrett, M., Leisenring, M., Sahu, S., Pankani, D., Poresky, A., Questad, A., Strecker, E., Weinstein, N., and Venner, M., 2014, Long-term performance and life-cycle costs of stormwater best management practices: National Cooperative Highway Research Program Research Report 792, 148 p., accessed October 2, 2020, at https://doi.org/10.17226/22275.

Tilley, J.S., and Slonecker, E.T., 2006, Quantifying the components of impervious surfaces: U.S. Geological Survey Open-File Report 2006-1008, 33 p., accessed June 23, 2020, at https://doi.org/10.3133/ofr20071008.

U.S. Geological Survey, 2014, National land cover database (NLCD) 2011 land cover conterminous United States: U.S. Geological Survey data release, accessed May 27, 2021, at https://doi.org/10.5066/P97S2IID.

U.S. Geological Survey, 2020, StreamStats-Streamflow statistics and spatial analysis tools for water-resources applications: U.S. Geological Survey database, accessed December 7, 2020, at https://streamstats.usgs.gov/.
U.S. Geological Survey, 2021, USGS water data for the nation: U.S. Geological Survey National Water Information System database, accessed June 1, 2021, at https://doi.org/ 10.5066/F7P55KJN.

Van Buren, M.A., Watt, W.E., and Marsalek, J., 1997, Applications of the log-normal and normal distributions to stormwater quality parameters: Water Research, v. 31, no. 1, p. 95-104. [Also available at https://doi.org/10.1016/S00431354(96)00246-1.]

Wang, Y.R., 2013, A method to estimate effective impervious surface and its application in pollutant loading computation: Tufts University, UEP 231 Introduction to GIS final paper, 17 p., accessed December 4, 2020, at https://wikis.uit. tufts.edu/confluence/download/attachments/57780329/ Final_Paper.pdf?api=v2.

Washburn, B., Yancey, K., and Mendoza, J., 2010, User's guide for the California impervious surface coefficients. California Environmental Protection Agency, 47 p. [Also available at https://oehha.ca.gov/media/downloads/ ecotoxicology/document/iscusersguide.pdf.]

Weaver, J.C., Granato, G.E., and Fitzgerald, S.A., 2019, Assessing water quality from highway runoff at selected sites in North Carolina with the Stochastic Empirical Loading and Dilution Model (SELDM): U.S. Geological Survey Scientific Investigations Report 2019-5031, 99 p., accessed August 19, 2020, at https://doi.org/10.3133/ sir20195031. 

For more information about this report, contact: Director, New England Water Science Center

U.S. Geological Survey

10 Bearfoot Road

Northborough, MA 01532

dc_nweng@usgs.gov

or visit our website at

https://www.usgs.gov/centers/new-england-water

Publishing support provided by the

Pembroke Publishing Service Center 
